\title{
Intra-household Inequality, Fairness and Productivity. Evidence from A Real Effort Experiment
}

\author{
Faith Masekesa
}

Alistair Munro

November 2018

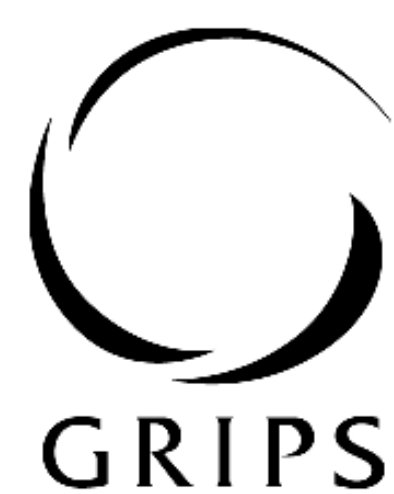

National Graduate institute FOR POLICY STUDIES

National Graduate Institute for Policy Studies

7-22-1 Roppongi, Minato-ku,

Tokyo, Japan 106-8677 


\title{
Intra-household Inequality, Fairness and Productivity. Evidence from A Real Effort Experiment.
}

\author{
Faith Masekesa, Alistair Munro* \\ National Graduate Institute for Policy Studies (GRIPS), Japan.
}

\begin{abstract}
This paper investigates experimentally how changes in wage rates and entitlements affect individual productivity in lab-in-the-field experiments run with married couples from rural regions in Uganda. We design a game in which the production task itself is straightforward, but where the rules governing payment vary across subjects and between rounds. In some cases, all the value of output goes to the husband; in other cases all goes to the wife; in other cases the value of output is shared equally and finally in some cases each spouse receives income according to only their own output. To consider the effects of wage inequality we vary the price paid for each completed item so that the ratio of male to female wages varies from 0.5 to 2 . All this is done transparently so that both partners know the rules of the game. The results generally indicate that a rise in relative wages lowers relative effort, a result that is contrary to the most straightforward interpretation of standard models of the household, but compatible with some models of fairness. Men do not generally respond strongly to treatment. In contrast, women's labour supply is strongly backward bending when all income goes to the husband, but effort rises with wages when each spouse gets to keep their own earnings. The results therefore suggest that the effects of reforming or removing one inequality may depend critically on the existence of other inequalities.
\end{abstract}

Keywords: household, experiment, family, Uganda, fairness

${ }^{\star}$ Our thanks are due to Dick Sserunkuuma, George Sentumbwe, Tomoya Matsumoto, Chika Yamauchi and the REPEAT survey team for data collection and assistance on task design. We gratefully acknowledge funding from the National Graduate Institute for Policy Studies for piloting work and from JSPS Kakenhi Grant Number 25101002 for the main field work.

*Corresponding author. National Graduate Institute for Policy Studies (GRIPS), Roppongi 7-22-1, Minato-ku, Tokyo, Japan, 106-8677. Email: alistair-munro 'at' grips.ac.jp

November 23, 2018 


\section{Introduction.}

Often, individuals hold views on what kinds of differences are fair or acceptable and this can affect the degree to which they are willing to tolerate inequality (Akerlof and Yellen (1990), Fehr and Schmidt, 1999, Breza et al. (2017). Experimental methods have been widely used to explore attitudes to inequalities within teams or groups (e.g. Charness and Kuhn (2007) Greiner et al. (2011)), where the results show that when wages or rights differ for reasons unconnected to productivity, then many individuals are uncooperative or unproductive. Since such groups are usually assembled for the purposes of the experiment, then the natural question is whether inequalities within established groups are also relevant for productivity. Now, perhaps the most widespread group in human society is the household and here we have plenty of inequality (World Bank (2012)) and observational evidence of perceptions of unfairness and uncooperative responses (Agarwal (1997), Sen (1987), Apusigah (2009)). In this research, therefore, we run an experiment that examines how entitlements and wage rates affect the supply of effort in a real-effort task in an intra-household setting. Our interest is whether such behaviour manifests itself in the controlled setting of an experiment or whether behaviour can be better explained by more straightforward models of household behaviours, such as cooperative or non-cooperative models. Our participants are married couples from rural regions across Uganda. We design a game in which the production task itself is straightforward and identical for men and women, but where the rules governing payment vary across subjects and between rounds. The specific design is framed by the predictions of several standard models of household allocation, namely the collective model (Chiappori, 1992), the unitary model (Becker, 1991) and non-cooperative models (Chen and Woolley, 2001). Each of these models has predictions for how relative effort should respond to changes in relative wages and property rights. In particular we vary the relative wage rates of husbands and wives and we vary the property rights over the income generated by the couple. In doing this we keep the rules for payment and output transparent for both partners, with the exact wages and allocation rules determined by random draws made by the individuals concerned so that it is clear that the payment rules are arbitrary.

Aside from the desire to scrutinise theoretical predictions under realistic, but controlled conditions, the experiment is motivated by two quite separate literatures. First, against a background of widespread and continuing gender inequalities with respect to ownership of property (land) and wages in Africa (Deere and Doss (2006); World Bank (2012)), there has been a continuing debate about the link between empowering women and economic prosperity. Boserup (1970) argues that unless females are granted equal access to productive resources, poor countries cannot develop. Similarly, Agarwal (1994) suggests that women's ownership of land improves women's productivity. At the macro level Schober and Winter-Ebmer (2011); Kabeer and Natali (2013) are among recent papers that suggest that there is no trade-off between gender equality and productivity. One aim of this research is to provide some causal evidence on the link between house- 
hold inequalities and productivity. Second, though there has been growing interest in experiments that examine the decisions of married couples (e.g. Iversen et al. (2010), Hoel (2015), Dasgupta and Mani (2015)) the role of production and the rules of entitlement in intra-household decisions has been largely neglected (though see Schröder et al. (2013), Couprie et al. (2015), Cochard et al. (2018) and Aoyagi and Munro (2018) for a few, recent exceptions), despite the fact that, in many societies, production is a fundamental aspect of household livelihoods. Many of the pre-existing experiments using modified public good or dictator games and find that few households make decisions that are efficient. An unresolved issue is whether efficiency is also a feature of behaviour in production tasks. At the same time, there is a growing interest in behavioral issues such as fairness and how it affects productivity (Charness and Kuhn (2007), Liu-Kiel et al. (2013)). While there is no standard theoretical model of how considerations of fairness might specifically affect intra-household behaviour, we consider this issue when designing the experiment.

The central result of this paper is that generally higher relative wages lower relative effort. The exception to this general pattern is found in the case where partners are paid separately, so that there are no fiscal externalities from production within the game itself. On the assumption that income effects for a two-hour experiment are small, the reduction in relative effort is contrary to the predictions of most household models, particularly those that assume some kind of efficiency in the household. In such environments, a rise in one person's wage relative to the other should shift productive effort to the person with the higher wage. Secondly, we find that changing the rules of entitlement - that is who receives the money from production - does not have a systematic effect on effort levels, though there is some evidence that men are less productive when they do not control the resultant income and women are more productive when rewards from production are paid separately and individually. Most fundamentally, we find that the effects of changing wage inequality depends on the entitlements to income in the experiment. In other words, wage inequality and property rights inequality interact. Specifically, women's effort is most sharply affected when all the income produced goes to the husband and this is what drives the average results for the effects of wages on relative effort. When women's wages rise, but the income goes to the husband, women lower their effort. The fact that the effects of changes in wage inequality depend on the pattern of property rights suggests that changes in behaviour in response to changes in inequalities may not be additive. A reform that equalizes property rights may have little effect on intra-household effort and a reform that narrows the wage gap may also have a small effect or a counterproductive impact on output compared to the consequences of combining the reforms.

The rest of the paper is organized as follows. Section 2 describes the background and provides an exposition of the theoretical ideas underlying the experimental design. The experiment design is introduced in section 3 and section 4 describes the implementation process. The results are presented in section 5 . Section 6 concludes by highlighting our 
main findings.

\section{Background.}

A particular reason for emphasizing the potential importance of evidence on the impact of intra-household inequality on productivity comes from policy debates over empowering women. Such issues are important around the world, including most African countries where gender inequality with respect to property rights and wages are very large (Doss, 2013). As we noted in the introduction, there is strong evidence of the persistence of gender disparities in Africa (Appleton et al. (1999); Lastarria-Cornhiel (2003); Deere and Doss (2006); World Bank (2012); Asiimwe (2014)) and this includes the specific case of Uganda (Doss et al., 2012). Titled land often remains the de facto preserve of wealthy households and within households; men are mostly likely to hold formal title (Ali et al., 2016). Women's lack of access to land is highlighted as one of the sources of inequality between women and men (Jones, 1983). The associated empirical literature suggests that there are three channels through which property rights can influence land related investment namely; freedom from expropriation, better access to credit and improved land transferability (Feder and Nishio, 1998). Boserup (1970) and Agarwal (1994) have therefore argued that empowering women through strengthening their rights over land will also contribute to economic growth and development by raising their productivity. However, despite these claims, gender discrimination in land rights is prevalent in many parts of the world, including Africa (Deere and Doss, 2006). In various African countries including Uganda Lastarria-Cornhiel (2003), the rural development programs continue to grant primary land rights to the husband in a bid to stimulate agricultural efficiency and productivity, raising the question whether this kind of policy will yield the desired outcomes if it maintains or raises intra-household inequalities.

As for our study site, there is continuing evidence of high gender inequality in land ownership in Uganda: women own and control only $7 \%$ of the land even though approximately 70 percent of smallholder farmers are women. ${ }^{1}$ Gender disparities also exist in the country's labour market; there is evidence of a substantial gender wage gap in Uganda (Appleton et al. (1999); Kagundu and Pavlova (2007)). Similarly, Kasirye (2011) reports that nearly half of the women in rural Uganda are unpaid workers on family farms, however, only $18 \%$ of the men were classified under the unpaid category. The lack of rights

\footnotetext{
${ }^{1}$ Not surprisingly therefore, women's land rights are high on the agenda of the women's movement in Uganda (Asiimwe, 2014). The Uganda Land Act includes a clause that requires spousal consent before land acquired during marriage is sold, but the clause requiring co-ownership of land by spouses was not included, even though it had been approved by members of parliament (Doss et al., 2014). According to Lastarria-Cornhiel (2003), other provisions in the Land Act appear to discriminate against women; for instance, it states that family land is represented by the head of the family (in most cases a man) so men have been given the legal power to make all transactions with respect to family land, making this person the owner of the property.
} 
over land coupled with very low or zero wages may make rural women more vulnerable to poverty (Doss et al., 2014). ${ }^{2}$

Intra-household property rights have been examined in the context of women's bargaining position within the household. Wiig et al. (2012) and Holden and Bezu (2013) for recent examples, find a positive significant impact on women's empowerment in Peru from legal reforms that strengthen women's legal rights. A few studies assess the impact of spousal co-ownership of land on agricultural productivity (Newman et al. (2015); Ovonji-Odida et al. (2000)). Ovonji-Odida et al. (2000) for example, in their short study in Uganda, find that the majority of women interviewed would change; (i) the way they made their labour available on the farm, (ii) their decision making in terms of crop choice, (iii) the investment they make on the land (for example, contributing their savings to purchase farm machinery and tools) if they are given co-ownership of family farm. This qualitative data is suggestive of a productivity impact but lacks firm evidence.

Away from observational evidence, the pre-existing experimental evidence on rights and productivity comes from a limited number of sources: first, in a series of papers on intrahousehold experiments run in India, Ethiopia and Nigeria, (Kebede et al., 2014; Munro et al., 2014, 2010) the authors have some treatments involving production. ${ }^{3}$ In these games played with couples, some treatments involved a production task, where in order to earn their endowments the married couples, individually and separately had to assemble and fill matchboxes. Though the aim of the exercise was to test whether earning the endowment affected behaviour in subsequent allocation and public good games, some individuals fell short of the ou tput target. Analysis of the data suggests that the productivity of individuals was related to treatment and individuals with fewer control rights tended to produce less. Meanwhile in Germany, Schröder et al. (2013) run games with partners in which the individuals complete mazes to earn rewards that are paid and taxed at different rates. The authors find that effort rate is not generally sensitive to tax or wages, except that men's effort is lower when their pre-tax wage is lower. Since the same effect is not present for changes in tax rates that produce the same net wage they conclude that the men's behaviour might best be explained as an issue of identity. Such a conclusion concurs with the work of Couprie et al. (2015) in France who find that when tasks are gendered (e.g. sorting socks or tightening bolts), assignment of responsibilities sometimes goes against the pattern of specialisation dictated by comparative advantage.

\footnotetext{
${ }^{2}$ As our own data shows, the relationship between formal control of assets and control of income and expenditure within the household may be quite complex. Even when women have formal rights, they make lack day to day control of resources. Conversely, even in the absence of formal rights, women may be able to affect household decisions, particularly if they have some other sources of bargaining power.

${ }^{3}$ Munro et al. (2013) in Uttar Pradesh, India compare the productivity of several hundred mixed sex teams of four in a digging task performed under NREGA and find that productivity is nearly $50 \%$ higher when spouses work in the same team, but the authors do not manipulate the control rights to output, so wider conclusions are harder to draw.
} 
The link between property rights and productivity is well-established, both for individuals and for groups, but there are also behavioural dimensions to inequality. Group-based inequalities often have a large impact on the well-being of individuals (World Bank, 2005), while inequality caused by exogenous circumstances such as gender or ethnicity can also discourage individual effort to the detriment of economic growth as well as damage perceptions of fairness in society ( Akerlof and Yellen (1990)). Wage differences based on discrimination rather than underlying productivity can adversely influence individuals' work effort (Fehr and Schmidt, 1999). Meanwhile, property rights matter not just because they determine who controls which resources and set the incentives that property owners face (Carruthers and Ariovich (2004)), but also because rights perceived as unfair may affect productivity.

The sparse literature on households does not focus on any link between inequality, perceived fairness and productivity, but outside it there are a significant number of experimental papers that do investigate the impact of in-game inequality. In some papers in this extensive literature there is no real effort as such - rather subjects choose the 'gift' they would like to make to another player who takes on the role of employer. Charness and Kuhn (2007), for example, in gift-exchange games run with students, find that the larger the wage "gift" a worker receives from the firm, the larger the wage gift each worker provides in return. They also find that worker's effort is not responsive to co-worker wages. On the other hand, Gächter and Thöni (2010) using three-person gift exchange experiments find that disadvantageous wage discrimination leads to lower efforts, however, participants who are paid more do not increase effort on average. When effort is made real as part of the experiment, inequality between players also affects productivity. In Liu-Kiel et al. (2013) there is some real-effort by the participants while Greiner et al. (2011) in a real effort experiment finds that wage inequality for the same task has a positive effect on task accuracy for the higher paid students and a negative effect for the lower paid. Greiner et al. (2011) also observes that with public information, lower paid workers shirk more and higher paid workers put in more effort.

Though these kinds of experiments provide some interesting points of comparison, the implication for intra-household behaviour is really not clear. For, as we emphasize in the next section, in some household models the question of who receives the money is irrelevant to the question of how much effort individuals puts into the task; similarly the level of effort by partners depends on wage levels rather than relative wage.

\subsection{Household models: Cooperation, Non-cooperation and Fairness.}

In order to understand the theoretical relationship between wages, property rights and output we briefly consider examples of three well-known classes of models of the household: the unitary model (Becker (1974)), the collective model (Chiappori (1992)) and the non-cooperative model (Chen and Woolley, 2001) in the context of our experiment. In a two-person model, the value of output produced in the experiment by person $i=1,2$ is $w_{i} a_{i} e_{i}$ where $w_{i}$ is the wage rate faced by person $i$ in the task, $a_{i}$ is productivity 
in units per minute and $e_{i}$ is effort. Individual preferences of the two agents over income available for consumption, $y$, are summarized by the increasing, twice differentiable and concave utility functions, $u$ and $v$ respectively. Each person, $i=1,2$ suffers effort costs $c_{i}\left(e_{i}\right)=e_{i}^{2} / 2$. For simplicity we make the effort costs homogeneous, but we also can think of someone with high $a_{i}$ either as someone with relatively high productivity or as someone who does not find it painful to work. The household when choosing collectively decides according to the function $W$, within which a weight of $\lambda$ is attached to person 1's interests and $(1-\lambda)$ is attached to the interest of person 2 . In the unitary model, $\lambda$ is a fixed parameter independent of the actions of the players, their fall-back utilities and so on. In the Pareto efficient model (Browning and Chiappori (1998)), $\lambda$ may depend on a number of factors including outside options and property rights to output.

$$
W=\lambda\left(u\left(x_{1}, z\right)-c_{1}\left(e_{1}\right)\right)+(1-\lambda)\left(v\left(x_{2}, z\right)-c_{2}\left(e_{2}\right)\right)
$$

The household income constraint is $x_{1}+x_{2}+z=y=y_{0}+w_{1} a_{1} e_{1}+w_{2} a_{2} e_{2}$ where $y_{0}$ is income from outside the experiment. For notational simplicity, we suppress $y_{0}$ in what follows. Since the problem is separable in $e_{i}$ we can treat it as a two-stage problem: maximize $\mathrm{W}$ with respect to $x_{i}, z$ for given y and then maximize $\mathrm{W}$ with respect to $e_{i}$, treating $u$ and $v$ as functions of $\mathrm{y}$ and using the budget constraint to substitute out $\mathrm{y}$. This produces the following first order conditions:

$$
\begin{array}{r}
w_{1} a_{1} U^{\prime}-\lambda e_{1}=0 \\
w_{2} a_{2} U^{\prime}-(1-\lambda) e_{2}=0
\end{array}
$$

Where $U(y)=\lambda u(y)+(1-\lambda) v(y)$ and $U^{\prime}=\lambda \frac{d u}{d y}+(1-\lambda) \frac{d v}{d y}$. Simplifying slightly we get:

$$
\frac{\lambda a_{2} e_{1}}{(1-\lambda) a_{1} e_{2}}=\frac{w_{1}}{w_{2}}
$$

It follows that for given $\lambda, e_{1} / e_{2}$ is increasing in the relative wage, $w_{1} / w_{2}$, the value of $e_{-i}$ falls if $w_{i}$ rises. I.e. the partner's effort falls if an individual's wage is higher.

The impact of a rise of $w_{i}$ on absolute effort is ambiguous. In particular $e_{i}$ may rise or fall if $w_{i}$ rises. If there are no income effects or they are sufficiently small because the wage change is temporary, then $e_{11}$ is positive and effort rises if absolute wages rise. ${ }^{4}$

\footnotetext{
${ }^{4}$ Berg (1961) makes an early critique of general claims about the possibilities of backward bending labour supply in sub-Saharan Africa. See Browning et al. (1985) for a general argument about the effect of a temporary rise in wages on labour supply in the context of an individual. Notwithstanding the general theoretical argument, a number of papers have found some evidence of labour supply falling in response to a temporary rise in wages, either in an experimental context ( Goette et al. (2004), Fehr and Goette (2007), Goldberg (2011) ) or in observational data from individuals who can control their hours
} 
Let us turn to $\lambda$. It can be shown that, for given $w_{1} / w_{2}$, relative output, $e_{1} / e_{2}$ is decreasing in $\lambda$ while $e_{1 \lambda}$ is negative and $e_{2 \lambda}$ is positive

To see this note that,

$$
\left[\begin{array}{l}
e_{1 \lambda} \\
e_{2 \lambda}
\end{array}\right]=H^{-1}\left[\begin{array}{c}
v^{\prime} w_{1} / \lambda \\
-u^{\prime} w_{2} /(1-\lambda)
\end{array}\right]
$$

Where $e_{i \lambda}$ represents the partial derivative of effort i with respect to $\lambda$.

Thus,

$$
\left[\begin{array}{c}
e_{1 \lambda} \\
e_{2 \lambda}
\end{array}\right]=\frac{w_{1} w_{2}}{|H|}\left[\begin{array}{c}
w_{2}\left(\left(v^{\prime} w_{1} / \lambda\right)\left(w_{1}^{2} U^{\prime \prime}-\lambda e_{2}\right)+U^{\prime \prime}\left(u^{\prime} /(1-\lambda)\right)\right) \\
-w_{1}\left(\left(v^{\prime} / \lambda\right) U^{\prime \prime}+\left(u^{\prime} /(1-\lambda)\right)\left(U^{\prime \prime}-\lambda e_{1}\right)\right)
\end{array}\right]
$$

The first row in the matrix on the right hand side of this expression is negative, while the second row element is negative. So $e_{1 \lambda}$ is negative and $e_{2 \lambda}$ is positive, meaning that $e_{1} / e_{2}$ also falls when $\lambda$ increases. In other words, a reduction in power makes individuals work harder in the collective household both in an absolute and relative sense. The intuition is that effort is costly and a reduction in power means a transfer of responsibility for effort to that person. This result does not depend on the absence of income effects or an assumption of a constant elasticity of cost with respect to effort.

\subsection{Non-cooperative models.}

We turn attention to the non-cooperative model, wherein each person chooses separately and simultaneously a) their level of effort, b) their consumption of a private good, $x_{i}$ and c) their contribution to a household public good $z=z_{1}+z_{2}$. The utility functions for the spouses are and we take $\mathrm{u}, \mathrm{v}$ to be increasing and concave in their arguments. As before, let y be total household income:

Case 1. $z_{i}>0$. It is well known (e.g. Warr (1983), Chen and Woolley (2001)) that in a Nash equilibrium of this game, as long as both $z_{i}>0$, then consumption of both $z$ and $x_{i}$ s depend only on the level of y and not the source of the income. In other words, we can continue to write $\mathrm{u}$ and $\mathrm{v}$ in the indirect form $u(y)$ and $v(y)$. The first order conditions can therefore be written as:

$$
\begin{aligned}
& w_{1} a_{1} u^{\prime}(y)-e_{1}=0 \\
& w_{2} a_{2} v^{\prime}(y)-e_{2}=0
\end{aligned}
$$

of work (Camerer et al. (1997) Crawford and Meng (2011) - though see Farber (2008) for a contrary view of the evidence -) or Dupas and Robinson (2013). They explain the results in terms of reference dependent preferences, coupled with shocks to wages. It is not clear to us whether our experiment, with its transparent procedures, fits this perspective. 
For changes in wages, suppose that the Nash equilibrium is stable and interior and let $\mathrm{J}$ be the Jacobean matrix associated with equation (5). Then,

$$
\left[\begin{array}{l}
e_{11} \\
e_{21}
\end{array}\right]=\frac{1}{|J|}\left[\begin{array}{cc}
w_{2}^{2} a_{2}^{2} v^{\prime \prime}-1 & -a_{1} a_{2} w_{1} w_{2} u^{\prime \prime} \\
-a_{1} a_{2} w_{1} w_{2} v^{\prime \prime} & a_{1}^{2} w_{1}^{2} u^{\prime \prime}-1
\end{array}\right]\left[\begin{array}{c}
-a_{1} u^{\prime}-a_{1} w_{1} e_{1} u^{\prime \prime} \\
-a_{2} w_{2} e_{1} v^{\prime \prime}
\end{array}\right]
$$

Where as above $e_{i 1}$ is the derivative of effort made by spouse i with respect to marginal changes in $w_{1}$. Stability of the equilibrium implies that the determinant of the Jacobean is positive. Using the concavity of the utility functions and the convexity of the cost functions we get that the sign of $e_{i 1}$ (the own effect) is ambiguous while the sign of $e_{i 2}$ is negative. Intuitively the cross-effect is negative because leisure (i.e. less effort) is a normal good. Therefore, as the wage of the partner rises and household income rises, then the other spouse slacks off. The own effect is ambiguous for similar reasons: higher wages increases the opportunity cost of leisure but at the same time the income effect lowers effort. Because of Warr (1983)'s theorem it does not matter for consumption who earns the income in the household. It follows that rules about ownership of rights to income also have no bearing on effort.

Case 2. $z_{2}=0$. For the case where one partner makes no financial contributions to the household public good, the predictions are somewhat different. In particular, property rights do matter. We omit detailed consideration of this case. However we note that because there is no incentive for person 1 to make any effort when they have no claims to the income from the game, then any switch to the 'person 2 takes all' rule leads to a predicted drop in $e_{1} \cdot{ }^{5}$

\subsection{Fairness.}

It is well-known that wage rates may influence work effort via feelings of equity and fairness in quite different settings (Akerlof and Yellen (1990); Farmer and Tiefenthaler (1995);Katz (1997) Charness and Kuhn (2007)). Farmer and Tiefenthaler (1995) is notable here in that they emphasize that intra-household behaviour may also depend on what is perceived is fair, but that it is not clear how individuals will define fairness in a household setting. Outside the context of the household, there are of course several wellused concepts. The widely cited inequality-aversion model Fehr and Schmidt, 1999, for

\footnotetext{
${ }^{5}$ While the assumptions of the model are standard, we note that $c(e)$ - the relationship between effort and its costs is assumed to be quadratic. If the relationship is linear or concave then a corner solution would be predicted. For the unitary and collective models this would mean that generically only 1 partner works flat out, though conceivably the identity of this person might be responsive to the wage rate rate. The key point though is that output for one person should be zero. For the non-cooperative model a person would either not work at all or work to their maximum and then be unresponsive to changes in wage rates and property rights except, possibly, jumping between maximum possible output and zero effort. Thus, in our experiment a lack of convexity in $c(e)$ does not mean that the signs of the predictions are simply reversed it also means that we should see partnerships with zero output by one partner and 'extreme' responses to changes in the parameters.
} 
example, postulates that people dislike inequality. Meanwhile, the key feature of Akerlof and Yellen (1990)'s model is an idea borrowed from sociology: that individuals offered renumeration below a fair wage will put in less effort, compared to individuals offered a wage at or above the fair wage. The definition of what counts as 'fair wage' will not always be clear when it comes to applying the idea to the household, but in the theory it could be the spouse's wage. In the non-cooperative model, ${ }^{6}$ this would mean that a rise in the spouse's wage reduces labour supply and a cut increases labour supply. Since this is actually consistent with the predictions of the standard non-cooperative model outlined above, the Akerlof-Yellen model has no distinguishing feature, except for the fact that fairness is felt asymmetrically: a wage below that earned by the comparator is viewed as unfair, whereas - unlike the Fehr and Schmidt (1999) model - there is no sense of unfairness felt when wages are above that of the comparator.

An alternative model of individual choice that allows agents to have different views on fairness, is that proposed by Cappelen et al. (2010). Consider a slightly modified version of that model with individual i whose utility $V_{i}$ has the form:

$$
V_{i}=y_{i}+\alpha y_{j}-\frac{\beta_{i}}{2} f\left(y_{i}-M_{i}\right)-\frac{e_{i}^{2}}{2}
$$

where $y_{i}$ is the income accruing to person $\mathrm{i}$ in the experiment and $y_{j}$ is the money going to the partner. The term $\alpha y_{j}$ (with $\left.\alpha \geq 0\right)^{7}$ is what makes this expression different from utility functions that are typically used to understand fairness or inequity aversion. The parameter $\alpha$ might represent altruism towards one's partner, in which case $\alpha=1$ means that the player attaches equal weight to their partner's income. However, given the possibility of ex-post redistribution of income and household public goods, $\alpha$ might represent the anticipated share or the utility to be had from any subsequent contribution to a household public good and thus has no necessary interpretation of altruism. ${ }^{8}$

The function $\mathrm{f}$ is positive, equal to zero at zero and monotonic on $\left|y_{i}-M_{i}\right|$, while $M_{i}$ represents the ideal distribution. Cappelen et al. (2007) and Cappelen et al. (2010)

\footnotetext{
${ }^{6}$ We concentrate on the non-cooperative model in this comparison, because it is not really clear how intra-household fairness concerns should be incorporated into the collective or unitary models. If though, disutility from increasing unfairness in the Akerlof-Yellen sense raises the costs of effort, for example, then the collective model's predictions are qualitatively unchanged from the standard version.

${ }^{7}$ In theory there is nothing to stop $\alpha$ being negative. Although this seems unlikely in the context of the household, it might occur for instance if the state of the relationship was particularly bad or if the person feared that their partner would misuse the cash on say, gambling or alcohol.

${ }^{8}$ Engelmann (2012) provides a critique of adding a concern for social efficiency directly into a fairness model. He shows that doing so in the Fehr-Schmidt model does not alter the properties of the model. Meanwhile in quadratic model such as the Bolton and Ockenfels approach, adding a concern for social efficiency can lead to an optimum that gives the majority share to the partner. That is not an issue here, because a spouse might directly benefit from income going to the partner and hence unfavourable inequality in the allocation of the game rewards might still be advantageous for the spouse.
} 
for example, set $f\left(y_{i}-M_{i}\right)=\left(y_{i}-M_{i}\right)^{2}$. With regard to $M_{i}$ they suggest four representative ideals of fairness: The egalitarian ideal is defined to mean that, whatever the circumstances, the optimal split of income is equal; equal opportunity means that a fair allocation is defined by relative effort and not affected by differences in productivity or piece rates; meritocratic means that a fair allocation reflects relative output and not the relative value of output, while the libertarian ideal is that each person receives the value of his or her output. For the egalitarian ideal, for example, $M_{i}=\left(q_{1}+q_{2}\right) / 2$ where $q_{i}$ is the value of output $=w_{i} e_{i} a_{i}$. This implies $\frac{\partial M_{i}}{\partial e_{i}}=\frac{w_{i} a_{i}}{2}$. Equal opportunity sets $M_{i}=\left(q_{1}+q_{2}\right)\left(\frac{e_{i}}{e_{1}+e_{2}}\right)$, meritocratic has $M_{i}=\left(q_{1}+q_{2}\right)\left(\frac{q_{i} / w_{i}}{q_{1} / w_{1}+q_{2} / w_{2}}\right)$ and finally, libertarian has $M_{i}=q_{i}$ so that $\frac{\partial M_{i}}{\partial e_{i}}=a_{i} w_{i}$.

Within this framework, as long as $\beta=0$, the individual has a straightforward and positive response to an increase in wage rates. Even if all the income accrues to the partner, as long as $\alpha>0$, a rise in own wage rate raises effort. When $\beta>0$, then the response is:

$$
\frac{d e_{i}}{d w_{i}}=\frac{\frac{\partial^{2} y_{i}}{\partial e_{i} \partial w_{i}}+\alpha \frac{\partial^{2} y_{j}}{\partial e_{i} \partial w_{i}}-\frac{\beta}{2}\left(f^{\prime \prime}\left(\frac{\partial y_{i}}{\partial e_{i}}-\frac{\partial M_{i}}{\partial e_{i}}\right)\left(\frac{\partial y_{i}}{\partial w_{i}}-\frac{\partial M_{i}}{\partial w_{i}}\right)+f^{\prime}\left(\frac{\partial^{2} y_{i}}{\partial e_{i} \partial w_{i}}-\frac{\partial^{2} M_{i}}{\partial e_{i} \partial w_{i}}\right)\right)}{1+\frac{\beta}{2}\left(f^{\prime \prime}\left(\frac{\partial y_{i}}{\partial e_{i}}-\frac{\partial M_{i}}{\partial e_{i}}\right)^{2}-f^{\prime}\left(\frac{\partial^{2} M_{i}}{\partial e_{i}^{2}}\right)\right)}
$$

For example, suppose $f(x)=(|x|)^{\gamma}$ with $\gamma>0$, then for the libertarian ${ }^{9}$ under the partner-takes-all regime, equation 8 becomes:

$$
\frac{d e_{i}}{d w_{i}}=\frac{\alpha a_{i}-\frac{\beta a_{i} \gamma}{2}\left(a_{i} e_{i} w_{i}\right)^{\gamma-1}(\gamma-2)}{1+\frac{\beta}{2}\left(\gamma(\gamma-1)\left(a_{i} e_{i} w_{i}\right)^{\gamma-2} a_{i}^{2} w_{i}^{2}\right)}
$$

while, for the libertarian under the separate regime, equation 8 becomes:

$$
\frac{d e_{i}}{d w_{i}}=a_{i}
$$

Thus is it possible for labour supply to be upward sloping under separate payment and to have a negative slope when all payment goes to the partner, provided $\alpha$ is sufficiently small and $\gamma<2 .^{10}$

We now turn to a discussion of the experimental design.

\footnotetext{
${ }^{9}$ In general, if the rule in the experiment matches the fairness norm then labour supply is upward sloping, because then $f=0$. When the fairness norm deviates from the rule in the experiment, the predicted pattern of behaviour becomes rather complicated, so we just discuss the libertarian case to illustrate the point that the slope of labour supply can vary according to the rule in the experiment that is used to allocate income.

${ }^{10}$ In many widely used models of fairness, a quadratic function $(\gamma=2)$ is used for convenience. As can be seen from the numerator, this does not allow the possibility of a backward bending labour supply curve for the model in equation 9. Though we do not spell it out here, $\gamma<2$ also allows a negative slope
} 


\section{Experimental design.}

Each couple performs the same production task twice (details in the next section) under a piece-rate regime. We use four variations of how the money from each task is divided: "Paid separately" in which each individual keeps what she/he earns from completing their task; "Wife gets all." where all the money goes to the wife; "Husband gets all" in which all the money accrues to the husband and lastly, "Sharing" in which the money made by the husband and wife is added and divided equally between them. In addition, we vary the piece rate for spouses independently such that an individual can either earn 300USh or 600USh for each successfully completed straw. In total therefore there are $4 x 4=16$ possible combinations of entitlements and wage rates for a couple.

Our hypotheses are based on the household models of the previous section and they are summarized in Table 1 below. Suppose that $\lambda$ represents the weight on the wife, and let $\lambda_{f}$ represent the weight when the woman ('female') takes all the income; $\lambda_{s}$ represents the weight when income is paid separately, $\lambda_{h}$ is the weight when all income is split equally ('halved') and $\lambda_{m}$ is the weight when income is given to the male partner. It seems reasonable that in the collective model, changes in the property rights in the experiment will have only a small impact on the long-term weights attached to each partner. Nevertheless they might be expected to show some shift. In this case, it seems reasonable that the weight on the wife's interest is highest when all the money goes to the wife and lowest when all the money goes to the husband, but it is not clear how to rank $\lambda$ between the other two cases so that $\lambda_{f}>\lambda_{s}, \lambda_{h}>\lambda_{m}$.

Firstly, let us focus on the property rights predictions. The unitary model assumes that all income is pooled and the identity of the income recipient or the person controlling an asset does not influence household behavior. This means that irrespective of whether the property rights are given to either the wife or husband, the household output remains the same. Therefore, under the unitary model assumptions, both male and female participants will be expected to be insensitive to variations in entitlements. Similarly, in the case of the non-cooperative model discussed in the previous section, it follows that as long as $z_{i}>0, i=1,2$, then the property rights allocation of the earnings from the experiment do not affect effort levels. In contrast, under the collective model, with $\lambda_{f}>\lambda_{s}, \lambda_{h}>\lambda_{m}$, entitlements are expected to influence the output produced by individuals. Under the collective household, individuals work harder both in an absolute and relative sense when property rights change in favour of their spouse.

Secondly, we consider the impact of changes in wages and relative wages. In the collective model, a change in wages has a direct effect, but also has an indirect effect. To the extent that the weight attached to an individual's interest is increasing in their own wage and decreasing in their partner's wage, the effects of changes on $\lambda$ go in the opposite

under the equal sharing rule for a libertarian, but it implies an upward sloping supply curve when the player controls all income. 
Table 1: Summary of Standard Predictions.

\begin{tabular}{ccccc}
\hline Effect on Model Increase or change in variable & Effect on & Unitary & Collective & Non-cooperative \\
\hline$w_{1} / w_{2}$ & $e_{1} / e_{2}$ & + & + & + \\
$w_{1}$ & $e_{1}$ & + & + & + \\
$w_{1}$ & $e_{2}$ & - & - & - \\
1 takes all $\rightarrow$ Other case & $e_{1} / e_{2}$ & 0 & + & 0 \\
Other case $\rightarrow 2$ takes all & $e_{1} / e_{2}$ & 0 & + & 0 \\
1 takes all $\rightarrow$ Half & $e_{1}$ & 0 & + & 0 \\
1 takes all $\rightarrow$ Separate & $e_{1}$ & 0 & + & 0 \\
1 takes all $\rightarrow 2$ takes all & $e_{1}$ & 0 & + & 0 \\
1 takes all $\rightarrow$ Half & $e_{2}$ & 0 & - & 0 \\
1 takes all $\rightarrow$ Separate & $e_{2}$ & 0 & - & 0 \\
1 takes all $\rightarrow 2$ takes all & $e_{2}$ & 0 & - & 0
\end{tabular}

Notes: In this table + and - mean an increase and decrease respectively. 0 means 'no effect' and should be distinguished from ? which means that the model allows any sign to the relationship. The non-cooperative predictions are shown for the case where both partners contribute to the household $\operatorname{good}(\mathrm{s})$. Changes in $w_{2}$ are symmetric and are therefore not shown.

direction to changes in w. Nevertheless, since $\lambda$ represents the weight in an ongoing, long-term relationship, we make predictions on the assumption that the indirect effect of changes in wages is small compared to the direct effect. In the case of the unitary model we therefore expect a positive relationship between relative wage and relative output. Secondly, an inverse relationship between individual wage and spouse work effort is expected. The unitary model has a fixed value for $\lambda$, so it makes the same predictions as the collective model. Similarly, as we saw in the previous section, in the absence of significant income effects, non-cooperative models suggest that the impact of relative wages on relative output is positive and the impact of wage on own effort is positive, while the impact on the partner's effort is negative or zero if income effects are truly absent. In short, in all three household models, the unitary, collective and non-cooperative a rise in an individual's wage is associated with a decline in the spouse's output. Furthermore, these three household models predict that the own wage has an ambiguous effect on own effort. The reason is that higher wages increases the opportunity cost of leisure but at the same time the income effect lowers effort. Because our experiment represents only a short-term intervention without a major effect on lifetime earnings, we assume for the purposes of prediction that the income effect is small relative to the substitution effect. In the absence of an economically significant income effect, then effort should rise if own wages rise.

Looking at table 1 we can see that if both partners contribute to household public goods, then the non-cooperative model and the unitary model cannot be distinguished in our experiment. However, the collective model is distinguished from the other two models by the differing impact of changes in property rights. All the standard models 
predict that a rise in relative wages raises relative effort. So the fairness model outlined in the previous section is distinguished from the other models by allowing a negative relationship between relative wages and relative output.

\section{Locations and experimental implementation.}

The experiment consists of two rounds of production, where the pay rates for each successful item and the identity of who received the payment is determined by a random draw, but is common knowledge within the couple. As for the work itself, after several pilots in Uganda and Japan we chose a portable, locally-sourced task where were confident we would be able to obtain variations in output across individuals. Participants are required to select 2 bands of each colour from a pile of bands which consists of four different colour bands. After selecting the bands they are supposed to tie the bands on a straw such that there are 8 identifiable bands in total on each completed straw. If a straw has more or less than 8 bands or has a wrong mix of colours or some bands are on top of one another, it is not counted as a completed straw.

The detailed game instructions are provided in Appendix 1. In all locations there is a basic design: invited couples are assembled in one space and led through a discussion of how to do the work and given opportunities to practice in the main local language. A demonstrator shows that 8 rubber bands (2 of each of four different colours) must be tied around a drinking straw and then all participants have a go at assembling a straw. If any of the participants makes a mistake the demonstrator highlights the mistake and shows them the correct way again. After questions have been answered, the experimenter explains how subjects are to be paid. They show the participants three bags namely: Entitlements bag, Wife bag and Husband bag. Then the participants come up to the experimenters couple by couple and draw (with replacement) from the opaque bags, cards governing payment for both the first and second round of the work, as well as a card for each round which shows who will receive the money made by the couple. Women draw their wage rate from the Wife bag; men use the Husband bag and they take it in turn to draw one card showing who gets the money in each round. Each person receives a sheet detailing the payment rule (see figure 1. The lower part of this sheet is filled in after the task has been completed). After all couples have gone through this process, men and women separate and are led to their production areas. After a further reminder of the rules, they begin 10 minutes of work, at the end of which correct straws are tallied by enumerators and subjects are individually reminded of the rules for the second round. The stock of materials for production is refreshed and then the second round proceeds, again for 10 minutes. At the end, the correct straws are tallied and both husband and wife are informed of the payment they will receive.

The rates of payment were chosen after two field pilots in Uganda and laboratory tests with the enumerators. The amounts paid per straw mean someone who produces 10 straws over the two rounds at 300 shillings per straw would generate the equivalent of 
Task 1.
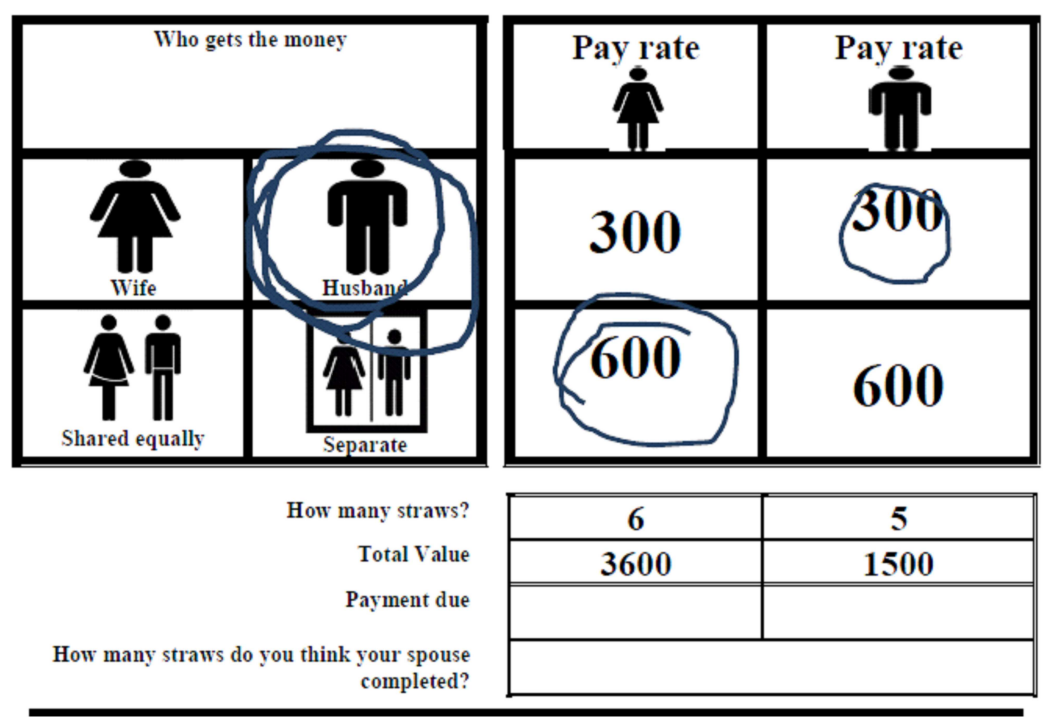

Figure 1: Payment Card

1 day's wages in most rural areas. Since the experiment, including instructions took at most 1.5 hours to complete, these payment rates are generous compared to other forms of work available to most of the subjects. To implement the experiment consistently we used a script written in English (see Appendix) which contained guidance on setting up the rooms as well as sections on how to inform the subjects. Since English is understood only imperfectly by many participants, the script was translated into the dominant local language by the experimenters and this was the language used for all oral explanations. Uganda has many local languages (about 18 were used in the course of this experiment), so in some locations the instructions were given twice in two local languages. In addition to the script we used a flipchart to remind subjects of the basic idea and each subject carried with her or him a copy of the personal payment rule for their household which included the wage rates for the spouse.

The sites used for the experiments varied considerably: in places with more than one room it would be impossible for spouses to monitor each other during the work, but in many cases we were using a single room school or church for the games. In this case we had to push men and women as far apart as possible, but it was possible that subjects could theoretically monitor their spouses. In practice this was quite difficult even in single-room locations. Men and women worked with their backs to one another often 10 metres apart in rooms that were dim and where it would be difficult to watch a spouses' effort without moving from the production site. Perhaps a more serious issue with small locations was the possibility that peer effects would be important in behaviour: 
men and women could see the work of the others in their group. Again without close scrutiny it would be impossible to see how many straws others were making, but we cannot rule out that in the smaller facilities, subjects could get some sense of how hard others were working. The worry in such a situation is that peer effects might dominate effects of variation in payment rates and property rights, so in the regressions that follow we control for peer output. However, what is worth emphasizing is that the separation of men and women meant that spouses could not directly observe the efforts of their partner.

Prior to the main fieldwork, we carried out a further pilot in 5 villages across the four regions of Uganda. In each location the experiment was undertaken after households had taken part in an extensive household survey. As far as possible we kept to the plan for the actual implementation. After this pilot we made some small changes, notably increasing the rates of pay, since productivity in the field was lower than amongst the enumerators. We also added points of extra clarification and emphasis to the script.

The 48 villages used in our experiments are part of the fifth round of the Research on Poverty, Environment, and Agriculture Technologies (RePEAT) panel survey which began in 2003 (Yamano et al. (2004), Mwesigye and Matsumoto (2016), Tanaka and Munro (2014)). The villages were selected from a stratified random sample across the four regions (Central, Eastern, Northern and Western). ${ }^{11}$ Therefore, our sample is a fair geographical representation of rural Uganda.

We invited all households with married couples who were part of the RePEAT survey and where both the partners were more than 18 years of age and under 50 . The implementation was carried out from September 2015 to January 2016, using four survey teams that is one team in each region. Each survey team comprises 7 to 9 people and they speak several languages which were relevant for communicating with participants in the different regions. In addition to the games described here and the prior survey, subjects also took part in some other, individual experiments organized by other researchers in the team. ${ }^{12}$ The order of the experiments was the same in each location, but randomly varied across locations and we include dummies for order effects in the regression analysis of the next section.

\section{Results.}

The total number of participants in the experiments is 420 . Table 2 shows the summary statistics of the background demographic and socio-economic characteristics of the participants. The household characteristics include household size, number of children,

\footnotetext{
${ }^{11}$ In 2003 the Northern region was not included because of ongoing violence in the region. In 2015 villages from the Northern region were added for the first time.

${ }^{12}$ The other experiments were (i) measurements of risk and time preferences and (ii) trust and modified dictator games.
} 


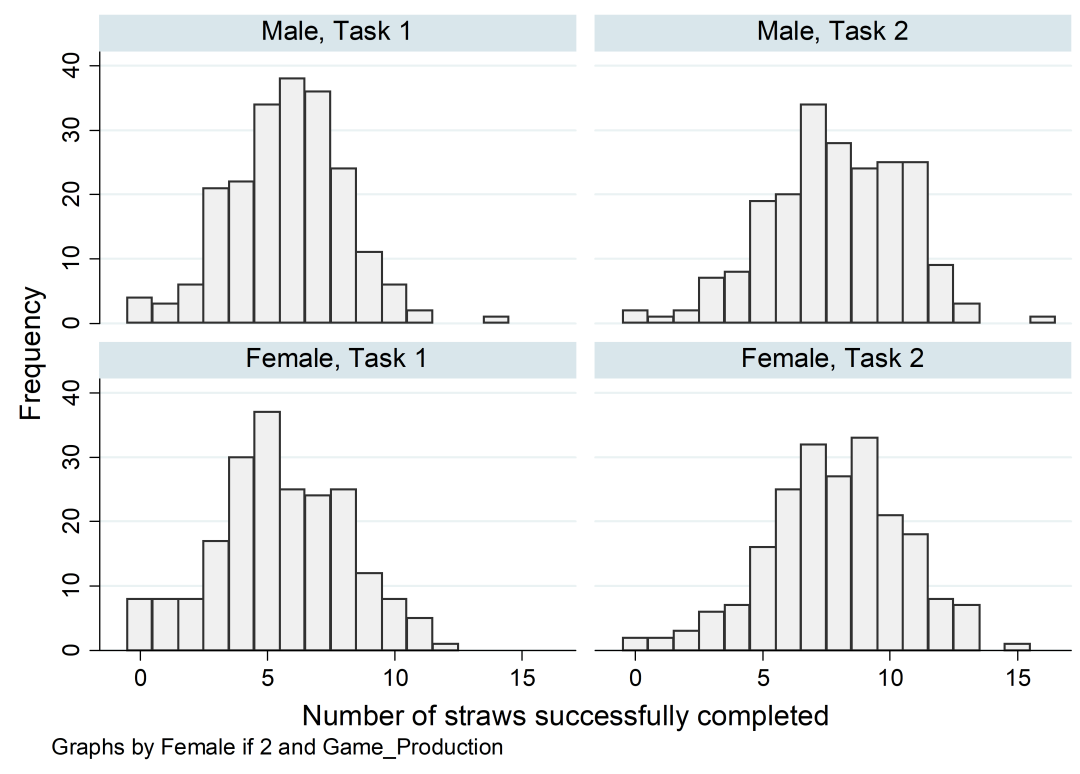

Figure 2: The distribution of output by round (task) and gender.

hours spent on earning activities, farm labour, education and age. The community-level information captured includes average land size per household, proportion of households who can afford more than two meals a day, number of tribes and distance to the nearest district town. The average age of the participants is 34 years and average highest grade of education completed is primary 6. Average number of people in a household is 10 and the number of children is about 4. Per capita cash expenditure on consumption of the household is on average US $\$ 48$, but for most households a significant part of consumption is in-kind based on domestic production. ${ }^{13}$ The mean share of farm labour is slightly lower for females compared to men. Meanwhile, the average distance of the communities to the district town is 17 miles, although this figure hides some variation.

In Figure 2we show the distribution of production which show that productivity rises in the second round, but also reflects the degree of variance in output.

The descriptive statistics for output and relative output in various categories are shown in Table 3 (see also Figure 3 ). There is a large and significant (at $p<0.001$, sign test) difference in output between the first and second rounds. Participants complete on average 2.17 more items in the second round compared to the first. However, the mean relative output is not significantly different between the two rounds. We find

\footnotetext{
${ }^{13}$ This figure is based on expenditure on everyday items. It omits lumpy items, defined as items occurring less than once per quarter. It is also a figure for cash expenditure, meaning that it omits consumption of own-production.
} 
Table 2: Summary statistics for demographic and socio-economic characteristics

\begin{tabular}{llll}
\hline Variable & Mean & Std. Dev. & Obs. \\
\hline Individual-level characteristics & 34.7 & 7.79 & 420 \\
Age & 6.05 & 3.40 & 420 \\
Years of education & 5.44 & 2.62 & 420 \\
Hours engaged in earning activities (per day) & 0.167 & 0.209 & 420 \\
Female power index & 0.326 & 0.325 & 400 \\
Female autonomy index & 0.054 & 0.173 & 420 \\
Female responsibility & 0.534 & 0.499 & 414 \\
Would hide no windfall money from spouse & 0.442 & 0.497 & 411 \\
Expect spouse to hide nothing from windfall & 0.167 & 0.373 & 408 \\
Share no winnings with spouse & 0.208 & 0.406 & 390 \\
Expect spouse to share no winnings & & & \\
\hline Household-level characteristics & 0.40 & 0.211 & 155 \\
\hline Female share of farm labour (most recent maize crop) & 0.074 & 0.262 & 404 \\
Female: some veto over land sale & 0.23 & 0.335 & 210 \\
Plots where wife is main decision maker & 0.634 & 0.167 & 210 \\
Congruence & 4.62 & 2.01 & 210 \\
Number of children & 8.43 & 3.68 & 210 \\
Household size & 48.01 & 39.98 & 210 \\
Per Capita Consumption Spending (US\$) & & & \\
\hline Community-level characteristics & 72.39 & 30.04 & 48 \\
\hline \% Households that can (currently) afford at least two meals a day & 2.53 & 1.94 & 48 \\
Average land size in acres per household & 3.19 & 5.71 & 48 \\
Total number of tribes in community & 16.98 & 14.73 & 48 \\
Distance to the nearest district town (miles) & & \\
\hline Notes Per capita cons
\end{tabular}

Notes: Per capita consumption is valued at the October 2015 rate of 1 US $\$=3690$ Uganda Shillings. Obs. refers to total observations available for that item. Female autonomy is an index based on two questions about whether a wife could make decisions about dress purchase or selling her own property without consultation; Female power is based on five questions: whether the wife was the main decision-maker for sending a child to school, crop growing, land acquisition, going to the clinic with a sick child and borrowing money. Female responsibility is based on two questions about whether the wife has responsibility for household finances and food decisions. Household characteristics are questions only asked at the household level. Congruence is the fraction of 13 questions about norms and household practices where both partners give the same answer. 
Table 3: Summary statistics for output.

\begin{tabular}{llllll}
\hline Variable & & Mean (Output) & Std. Dev & Mean (Relative Output) & Std. Error \\
\hline Game Round & Round 1 & 5.66 & 0.118 & 1.300 & 0.087 \\
\multirow{3}{*}{ Gender } & Round 2 & 7.86 & 0.130 & 1.185 & 0.073 \\
Sharing rule & Male & 6.83 & 0.131 & - & - \\
& Female & 6.66 & 0.142 & - & - \\
& Man gets all. & 6.76 & 0.195 & 1.219 & 0.078 \\
& Sharing & 6.51 & 0.167 & 1.254 & 0.111 \\
Wage rate & Paid separately & 7.02 & 0.189 & 1.082 & 0.066 \\
& Woman gets all. & 6.81 & 0.240 & 1.464 & 0.203 \\
Relative wage & Low & 6.68 & 0.135 & - & \\
(male wage/female wage) & High & 6.69 & 0.137 & - & 0.116 \\
& 0.5 & - & - & 1.361 & 0.063 \\
& 1 & - & - & 1.192 & 0.073 \\
\hline
\end{tabular}

that on average male participants complete 6.76 straws and females 6.68 straws, but this differences in average number of straws completed is not significant ( $\mathrm{p}$-value $=0.68$, two-tailed t-test).

Figure 3 is the key exhibit in this paper. It shows relative output (male / female) across the sharing rules for different relative wages. For the Paid Separately rule, higher relative wages appear to be associated with higher relative output. This is in keeping with the standard predictions. In contrast, for the other sharing rules, higher relative wage is associated with lower relative output. This is contrary to the standard predictions. Although it appears that this contrary pattern is strongest for the 'Woman gets all' in fact, as we show below the relationship is actually clearest for 'Man gets all'.

In Table 4 we present the results of tests of differences. In the final column of table 4, we note whether the direction of change is consistent with the standard predictions. As can be seen there are broadly two patterns in the data. First, when we consider the mean of relative output for different levels of relative wage. The average relative output declines as the relative wage rises from 0.5 , to 1 and 2 , respectively. We find significant differences in the relative output across the three relative wage categories (only at the $10 \%$ level in the first comparison). The lowest relative wage is associated with the highest relative output; this is opposite of the standard predictions. Ths produces our first main result:

Result 1: Contrary to the standard predictions, rises in relative wages are typically associated with falls in relative wages. The exception is the case where earnings are paid separately in which case higher relative wages do not lower relative output.

Turning briefly to absolute wages, the results show that on average the output produced is 6.6 straws when the spouse's wage rate is Ush300 and is 6.9 straws when the spouse's wage rate is Ush600. The average number of straws completed when the individual's wage is Ush300 is not significantly different from when it is Ush600 for either 


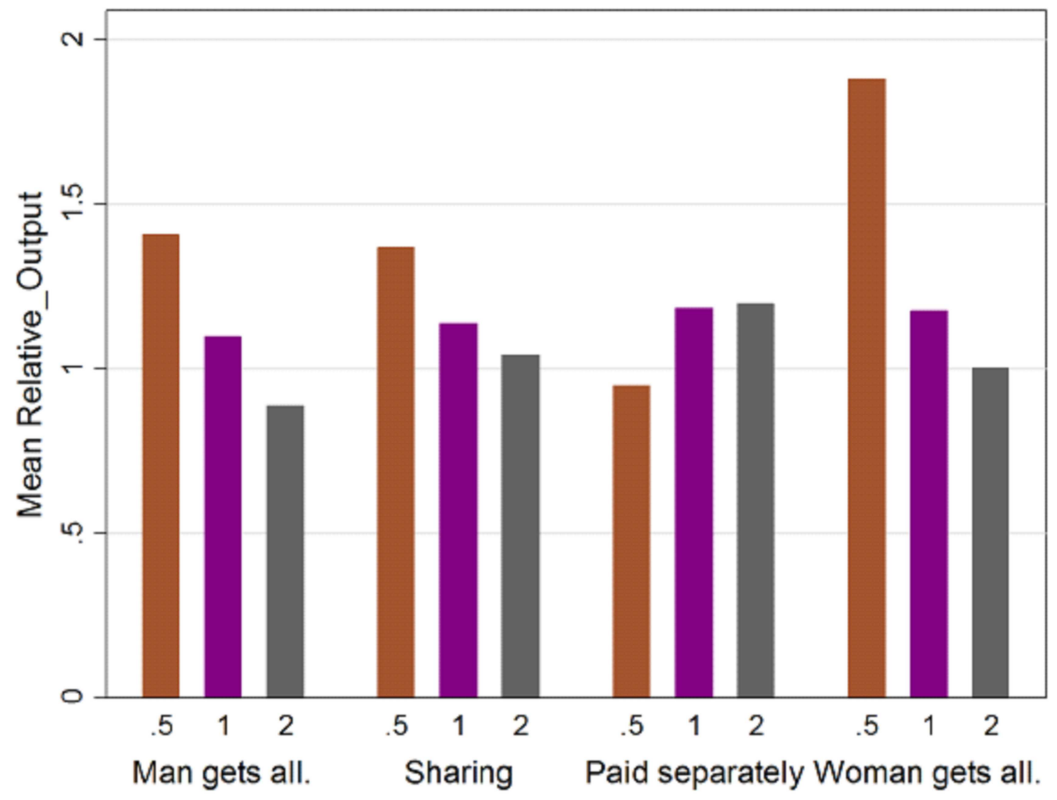

Figure 3: Relative Output.

men or women. Recall, the three standard household models predict that a rise in an individual's wage is associated with a decline in the spouse's output; however, our results do not in general support the prediction. In fact, the results go in the opposite direction and are significant at the $10 \%$ level for the effect of women's wages on men's effort.

The second broad pattern in the data is the absence of a clear relationship between sharing rule categories and outcomes predicted by the collective and unitary models. In Table 5 we present tests of how the control over earnings alters effort. Unlike the relative wage changes, there is no clear pattern to these results and nearly all are insignificant. The exception is the difference in relative output moving to Wife receives all income. Under the collective model this should increase male output relative to female and this is what occurs. However it is only the 'separate' to 'Wife receives all' comparison that is statistically significant at the $5 \%$ level. The "Paid separately" category has the highest average output (7.0) and "Sharing equally" category has the lowest average output (6.47). The difference between these two means is significant at the $5 \%$ level ( $p$-value $=0.043$, two-tailed t-test). We do not find significant difference in the average number of straws completed across other sharing rule categories.

\subsection{Econometric Results.}

We estimate two main equations; (i) the effect of relative wage and property rights on relative output and (ii) the impact of wages and rules of allocation on the absolute level of output. Firstly, we test the predictions on relative output using the following equation; 
Table 4: Tests of wage effects.

\begin{tabular}{ccccc}
\hline Effect on Model Increase or change in variable & Effect on & Difference & t-stat & Comment on sign \\
\hline$w_{1} / w_{2}(0.5 \rightarrow 1)$ & $e_{1} / e_{2}$ & -0.168 & -1.27 & Opposite to prediction \\
$w_{1} / w_{2}(0.5 \rightarrow 2)$ & $e_{1} / e_{2}$ & -0.429 & $-3.13^{* * *}$ & Opposite to prediction \\
$w_{1} / w_{2}(1 \rightarrow 2)$ & $e_{1} / e_{2}$ & -0.261 & $-2.70^{* * *}$ & Opposite to prediction \\
$w_{1} / w_{2}(0.5 \rightarrow 2) ;$ man takes all & $e_{1} / e_{2}$ & -0.550 & $-3.24^{* * *}$ & Opposite to prediction \\
$w_{1} / w_{2}(0.5 \rightarrow 2)$; equal shares & $e_{1} / e_{2}$ & -0.423 & -1.47 & Opposite to prediction \\
$w_{1} / w_{2}(0.5 \rightarrow 2) ;$ separate & $e_{1} / e_{2}$ & 0.039 & 0.29 & Matches prediction \\
$w_{1} / w_{2}(0.5 \rightarrow 2) ;$ woman takes all & $e_{1} / e_{2}$ & 1.001 & $-1.65^{*}$ & Opposite to prediction \\
$w_{1}($ low to high) & $e_{1}$ & 0.246 & 0.907 & - \\
$w_{1}$ (low to high) & $e_{2}$ & 0.027 & 0.091 & Opposite to prediction \\
$w_{2}($ low to high) & $e_{1}$ & 0.367 & 1.257 & Opposite to prediction \\
$w_{2}($ low to high) & $e_{2}$ & -0.418 & -1.430 & -
\end{tabular}

Table 5: Tests of earning ownership rights.

\begin{tabular}{ccccc}
\hline Effect on Model Increase or change in variable & Effect on & Difference & t-stat & Comment on sign \\
\hline Man takes all $\rightarrow$ Woman takes all & $e_{1} / e_{2}$ & 0.289 & 1.290 & Matches prediction \\
Man takes all $\rightarrow$ Half & $e_{1} / e_{2}$ & 0.074 & 0.534 & Matches prediction \\
Separate $\rightarrow$ Woman takes all & $e_{1} / e_{2}$ & 0.420 & $1.900^{*}$ & Matches prediction \\
Man takes all $\rightarrow$ Half & $e_{1}$ & -0.4567 & -1.284 & Opposite to prediction \\
Man takes all $\rightarrow$ Separate & $e_{1}$ & -0.342 & -0.918 & Opposite to prediction \\
Man takes all $\rightarrow$ Woman takes all & $e_{1}$ & -0.190 & -0.468 & Opposite to prediction \\
Man takes all $\rightarrow$ Half & $e_{2}$ & -0.258 & -0.702 & Matches prediction \\
Man takes all $\rightarrow$ Separate & $e_{2}$ & 0.694 & $1.734^{*}$ & Opposite to prediction \\
Man takes all $\rightarrow$ Woman takes all & $e_{2}$ & 0.115 & 0.252 & Opposite to prediction \\
Notes: ${ }^{* * *} p<0.01 ; * *<0.05 ;{ }^{*} p<0.10$ are for 2-tailed tests with unequal variance.
\end{tabular}




$$
O_{i}=\beta_{0}+\beta_{1} T+\sum_{t} \beta_{2 t} R_{i t}+\sum_{j} \beta_{3 j} X_{i j}+\sum_{t} \sum_{j} \beta_{4 j t}\left(X_{i j t} * R_{i t}\right)+\beta_{z} Z_{i}+\varepsilon_{i}
$$

where $O_{i}$ is the dependent variable, the natural log of relative output (where relative output $=$ husband output/wife output) of couple $\mathrm{i}^{14}$. The explanatory variables $\mathrm{T}, R_{i}$, $X_{i}$ are round dummy, log natural of relative wage (=husband wage rate/wife wage rate) and the sharing rule, respectively. For $X_{i j t}$, which is a set of $\mathrm{j}$ dummy variables for entitlements faced by person $\mathrm{i}$ in round $\mathrm{t}=1,2$, the base group is "Man gets all". $Z_{i}$ is a vector of individual and household characteristics as well as game-related variables. Errors are clustered at the community level.

The variables contained in $Z_{i}$ are: dummies for region 1, 2, 3 and 5 with region 1 as the base group; three dummy variables related to game order, 'coworking' used as a measure of shared labour in the farm and the fraction of land where the wife has some veto rights on sale, according to the husband; congruence - an index that measures the degree to which the spouses separately agree responses to thirteen different questions; ${ }^{15}$ household size, the log of household consumption used as a proxy for income and a dummy for whether the household is a member of the local majority ethnic group. We also include game-related variables because we carried out several different experiments during the RePEAT 2015 survey. The order in which these games were played in each community was randomly determined and we included dummies for this order.

In Table 6 we report three results. In the first equation we include only the parameters of the design, dummies for round, region and game order. The second equation adds in some controls based on household characteristics and the third equation adds in the parameters from the other round, since it is possible that subjects make fully-intertemporal decisions. The key result is in line with the basic statistical tests already given: there is a consistent negative relationship between the natural log of relative output and the $\log$ of relative wages. This result is robust to changes in specification. The second key result is that relative output is not directly sensitive to changes in entitlements. The third result is the positive coefficient on the interaction between separate payment and wages. This means that that when payments are made separately, there is no negative impact of relative wages on relative effort. In the third equation we bring in the variables from the other round and see that this makes little difference to the patterns of sign and significance. However there is some evidence that when payments are made separately in

\footnotetext{
${ }^{14}$ We use a $\log -\log$ specification for the relative wage equation as this allows the coefficients to be naturally interpreted as elasticities. If we use the simple ratios instead we get similar qualitative results to those shown in Table 6.

${ }^{15}$ Questions include agreement with normative statements such as 'a man should have final say in all household matters' as well as questions about who is the main decision-maker, for example when choosing whether to take a sick child to the clinic.
} 
the other round, relative output is lower in the current round.

Table 7 shows the marginal effects of the variables, allowing for interactions, estimated by the delta method at the mean values of all right-hand side variables. In the case of changes in the entitlement variable, the estimates are for discrete changes with 'man gets all' as the base case. For the relative wage variable the effect of a rise on relative output is significantly negative when the entitlement rule is 'man gets all'. On the other hand the effects are negative for 'Sharing' and 'women gets all' but not significantly different from zero. In the case of separate payments, however, the net effect of a rise in wages is positive at significant at the $10 \%$ level. The confidence intervale for the separate payments coefficient does not overlap with the confidence intervals for the Man gets all and Woman gets all case, but does overlap with the Sharing confidence interval. The other round parameters largely follow the same pattern. Here the Separate confidence interval does not overlap with those for Man gets all and Separate, but it does overlap with the confidence interval for Woman gets all. For changes in the value of entitlement, a move to 'Separate' reduces relative output - in other words the gap between male and female outtput closes when the partners are paid separately for their work. When the entitlement in the other round is altered there are no significant effects for Sharing and 'Woman gets all', but again there is a negative effect from moving to the 'Separate'. Note that there is no clear impact on relative output from moving from Man gets all to Woman gets all - it is only separation of payments that lowers the output gap between men and women.We summarize the results as,

Result 2. When partners are paid separately the gap between male and female output is lowered compared to the Man gets all case.

Although these changes are not supportive of the predictions, nevertheless to understand the data fully we need to look at what happens to individual output. That is what we proceed to discuss below, but before doing so, it is worthwhile noting a couple of other points from the estimates. There are negative coefficients on the cowork index variable and the log of consumption variable is positive and significant at the $10 \%$ level. The results therefore suggest that where women work alongside their husbands, the gap between male and female output is lower. What is not clear from this equation is whether this is due to lower male output, higher female output or some combination of the two. At the same time, the coefficient on consumption suggests that in relatively richer households, the gap between male and female output is larger.

In order to test the theoretical predictions for absolute output, we consider variants of the following equation;

$$
S_{i}=\beta_{0}+\beta_{1} T+\sum_{t} \beta_{2 t} W_{i t}+\sum_{j} \beta_{3 j} X_{i j}+\sum_{t} \sum_{j} \beta_{4 j t}\left(X_{i j t} * W_{i t}\right)+\beta_{z} Z_{i}+\varepsilon_{i}
$$

In equation (12), $S_{i}$ is how many straws an individual i successfully produced in 
Table 6: Relative Output.

\begin{tabular}{|c|c|c|c|}
\hline VARIABLES & Theory 1 & Theory 2 & Theory 3 \\
\hline Ln(relative wage) & $\begin{array}{c}-0.301^{* * *} \\
(0.110)\end{array}$ & $\begin{array}{c}-0.255^{* *} \\
(0.104)\end{array}$ & $\begin{array}{c}-0.258^{* *} \\
(0.107)\end{array}$ \\
\hline Sharing & $\begin{array}{c}0.089 \\
(0.085)\end{array}$ & $\begin{array}{c}0.054 \\
(0.092)\end{array}$ & $\begin{array}{c}0.036 \\
(0.085)\end{array}$ \\
\hline Separate & $\begin{array}{l}-0.018 \\
(0.085)\end{array}$ & $\begin{array}{l}-0.039 \\
(0.090)\end{array}$ & $\begin{array}{l}-0.045 \\
(0.086)\end{array}$ \\
\hline Woman gets all & $\begin{array}{c}0.068 \\
(0.089)\end{array}$ & $\begin{array}{c}0.024 \\
(0.089)\end{array}$ & $\begin{array}{c}0.040 \\
(0.100)\end{array}$ \\
\hline SharingxLn(relative wage) & $\begin{array}{c}0.268 \\
(0.163)\end{array}$ & $\begin{array}{c}0.172 \\
(0.172)\end{array}$ & $\begin{array}{c}0.188 \\
(0.200)\end{array}$ \\
\hline SeparatexLn(relative wage) & $\begin{array}{c}0.374^{* * *} \\
(0.128)\end{array}$ & $\begin{array}{c}0.370^{* * *} \\
(0.132)\end{array}$ & $\begin{array}{c}0.425^{* * *} \\
(0.130)\end{array}$ \\
\hline Woman gets all xLn(relative wage) & $\begin{array}{l}-0.021 \\
(0.228)\end{array}$ & $\begin{array}{l}-0.078 \\
(0.233)\end{array}$ & $\begin{array}{l}-0.066 \\
(0.235)\end{array}$ \\
\hline $\operatorname{Ln}($ relative wage, other round) & & & $\begin{array}{l}-0.187 \\
(0.135)\end{array}$ \\
\hline Sharing (other round) & & & $\begin{array}{l}-0.072 \\
(0.097)\end{array}$ \\
\hline Separate (other round) & & & $\begin{array}{c}-0.147^{* *} \\
(0.072)\end{array}$ \\
\hline Woman gets all (other round) & & & $\begin{array}{l}-0.043 \\
(0.096)\end{array}$ \\
\hline SharingxLn(relative wage, other round) & & & $\begin{array}{c}0.082 \\
(0.213)\end{array}$ \\
\hline SeparatexLn(relative wage, other round) & & & $\begin{array}{c}0.368^{* *} \\
(0.146)\end{array}$ \\
\hline Woman gets all $x \operatorname{Ln}$ (relative wage, other round) & & & $\begin{array}{l}-0.019 \\
(0.195)\end{array}$ \\
\hline Household size & & $\begin{array}{l}-0.009 \\
(0.008)\end{array}$ & $\begin{array}{l}-0.010 \\
(0.008)\end{array}$ \\
\hline Natural log of consumption & & $\begin{array}{l}0.084^{*} \\
(0.042)\end{array}$ & $\begin{array}{c}0.089^{* *} \\
(0.043)\end{array}$ \\
\hline Fraction of land where wife has veto right & & $\begin{array}{c}0.046 \\
(0.120)\end{array}$ & $\begin{array}{c}0.015 \\
(0.127)\end{array}$ \\
\hline Coworking Index & & $\begin{array}{c}-0.151^{*} \\
(0.088)\end{array}$ & $\begin{array}{c}-0.173^{*} \\
(0.093)\end{array}$ \\
\hline Congruence & & $\begin{array}{c}0.019 \\
(0.173)\end{array}$ & $\begin{array}{c}0.025 \\
(0.173)\end{array}$ \\
\hline Belongs to majority ethnic group & & $\begin{array}{l}-0.057 \\
(0.106)\end{array}$ & $\begin{array}{l}-0.090 \\
(0.112)\end{array}$ \\
\hline Round 2 dummy & $\begin{array}{l}-0.047 \\
(0.038)\end{array}$ & $\begin{array}{l}-0.042 \\
(0.039)\end{array}$ & $\begin{array}{l}-0.044 \\
(0.036)\end{array}$ \\
\hline Constant & $\begin{array}{l}-0.060 \\
(0.134)\end{array}$ & $\begin{array}{l}-1.056 \\
(0.648)\end{array}$ & $\begin{array}{l}-1.007 \\
(0.653)\end{array}$ \\
\hline Observations & 404 & 386 & 386 \\
\hline R-squared & 0.073 & 0.105 & 0.141 \\
\hline
\end{tabular}


Table 7: Relative Output Marginal effects.

\begin{tabular}{|c|c|c|c|c|}
\hline & \multicolumn{2}{|c|}{ Current round variables } & \multicolumn{2}{|c|}{ Other round variables } \\
\hline & $\mathrm{dy} / \mathrm{dx}$ & p-value & $\mathrm{dy} / \mathrm{dx}$ & p-value \\
\hline \multicolumn{5}{|l|}{ Ln(relative wage) } \\
\hline Man gets all & $-0.258 * *$ & 0.020 & -0.187 & 0.174 \\
\hline Sharing & -0.070 & 0.621 & -0.105 & 0.490 \\
\hline Separate & $0.166^{*}$ & 0.080 & $0.181^{* *}$ & 0.048 \\
\hline Woman gets all & -0.324 & 0.188 & -0.206 & 0.244 \\
\hline \multicolumn{5}{|c|}{ Entitlement variables } \\
\hline Sharing & -0.005 & 0.942 & -0.090 & 0.246 \\
\hline Separate & $-0.138^{*}$ & 0.055 & $-0.229 * * *$ & 0.001 \\
\hline Woman gets all & 0.054 & 0.656 & -0.038 & 0.703 \\
\hline
\end{tabular}

round $\mathrm{t}$, where $t=1,2$. The explanatory variables $T, X_{i}$, are the same as in equation (11). However, the vector $Z_{i}$ contains more variables (household size and Gender), than equation (11). "Household size" refers to the number of individuals within the household. The variables are defined as own wage rate and spouse's wage rate, respectively. Furthermore, we run equation (12) separately for male and female participants since we expect genders to respond differently to variations in spouse wages, entitlements and the peer rules. "Age" and "Spouse's Age" refer to the age of the participant and that of the participant's spouse, respectively. The variables "Education" and "Spouse's education" mean the number of years of schooling for the participant and the spouse, respectively. The "Average Peer output" is the mean output of other participants for each gender group in each community in that round. It is conceivable that individuals may react to the entitlements of their neighbours in the same way that subjects have reacted in individual real-effort experiments (Greiner et al., 2011). To allow for such spillovers we include two more variables: Peer rule 1 and Peer rule 2. We rank the entitlement categories by assigning values 1, 2, 3 and 4 representing "Man gets all", "Sharing equally", "Paid separately" and "Woman gets all", respectively. In other words, as the value of the variable increases female entitlement becomes stronger. ${ }^{16}$ In this context Peer rule 1

\footnotetext{
${ }^{16}$ We noted earlier that sharing equally might be viewed as a stronger entitlement compared to paid separately since the spouse gets a claim on the partner's output. We rank in this way because the security of the woman's earning is always increasing in the measure, but as a check we re-run the regressions with a switch of ranking and do not get materially altered results.
} 
is the rule most favourable to men faced by a person in the rest of the peer group while Peer rule 2 is the rule most favourable to women.

Equation (12) allows us to examine the effects of entitlements and wage rate on absolute output. In order to determine the gender specific treatment differences in productivity, we estimate the equation (12) separately for females and males; the results are shown in equations 1 and 2, respectively in Table 8. As an additional exercise we include equations for total output. In these equations, the 'own' wage etc. is the woman's wage and wage is recorded as ' 1 ' for the lower amount and ' 2 ' for the higher value.

Before looking at the impact of the experimental manipulations on effort, it is informative to consider briefly the other variables in Table 8. We can see the large jump in productivity that occurs in round 2 - only 15 subjects produced less in the second round, compared to the first and $87 \%$ produced at least one straw more. Younger people produce more as do those with more years of education. There is a strong peer effect a one unit increase in mean straw production by the rest of the group leads on average to about 0.41 extra straws for both men and women. Measures of wealth such as land holdings are not linked to productivity though there is evidence that men in households with higher expenditure produce more. For women, the degree to which they cowork or control their own plots is not linked to productivity. In contrast, it appears that where women co-work with their husbands or control planting decisions on more plots, male productivity is lower. ${ }^{17}$ Recall that relative output was diminishing in the coworking variable and increasing in the log of household consumption. From the absolute output equations we see that it is male behaviour that drives these results.

Recall that in the equations for relative output, the key result was that higher relative wages lowered relative output. To be consistent with this result, we expect a negative coefficient on own wages and a positive coefficient on the partner's wage. From the equations for women (with and without controls) we can see a large negative coefficient as per expectations. The corresponding coefficient for men shows the anticipated sign but is not significant. Similarly the coefficients on partner's wages are not significant. Here though the coefficient in the women's equation has a negative sign. There are a number of interaction terms here and a quick perusal of the Table suggests than in many cases, the direct effect of a price change is largely cancelled out by the interaction terms. That is indeed the case as Table 9 shows. This table shows marginal effects evaluated at mean values of right hand side variables. It can be seen that when the full set of controls is included, the own wage effect is negative but not significantly so for women. Broken down by entitlement it is also clear that the average effect is driven by the effect when 'men get all'. Under other entitlement rules the effect of raising wages on women's output

\footnotetext{
${ }^{17}$ If straw productivity is linked to general industriousness, it is possible that this result represents reverse causality - i.e. women end up working more and controlling more when their husbands have lower productivity.
} 
Table 8: Absolute Output.

\begin{tabular}{|c|c|c|c|c|c|c|}
\hline VARIABLES & Women & Men & Total & Women - controls & Men - controls & Total - controls \\
\hline Price per straw (own wage) & $\begin{array}{c}-1.981^{* * *} \\
(-3.68)\end{array}$ & $\begin{array}{l}-0.353 \\
(-1.00)\end{array}$ & $\begin{array}{l}-0.487 \\
(-0.71)\end{array}$ & $\begin{array}{c}-2.237^{* * *} \\
(0.520)\end{array}$ & $\begin{array}{c}-0.432 \\
(0.371)\end{array}$ & $\begin{array}{l}-0.598 \\
(0.643)\end{array}$ \\
\hline Partner's wage & $\begin{array}{l}-0.244 \\
(-0.45)\end{array}$ & $\begin{array}{l}0.449 \\
(0.75)\end{array}$ & $\begin{array}{l}-1.417 \\
(-1.37)\end{array}$ & $\begin{array}{l}-0.443 \\
(0.496)\end{array}$ & $\begin{array}{c}0.138 \\
(0.589)\end{array}$ & $\begin{array}{c}-1.839^{* *} \\
(0.856)\end{array}$ \\
\hline Sharing & $\begin{array}{l}-2.378 \\
(-1.57)\end{array}$ & $\begin{array}{l}-0.512 \\
(-0.31)\end{array}$ & $\begin{array}{l}-2.559 \\
(-0.94)\end{array}$ & $\begin{array}{c}-2.873^{* *} \\
(1.412)\end{array}$ & $\begin{array}{l}-0.854 \\
(1.376)\end{array}$ & $\begin{array}{l}-3.295 \\
(2.202)\end{array}$ \\
\hline Separate & $\begin{array}{c}-3.301^{*} \\
(-1.93)\end{array}$ & $\begin{array}{l}-0.961 \\
(-0.50)\end{array}$ & $\begin{array}{l}-4.152 \\
(-1.35)\end{array}$ & $\begin{array}{c}-3.983^{* *} \\
(1.559)\end{array}$ & $\begin{array}{l}-1.067 \\
(1.519)\end{array}$ & $\begin{array}{l}-4.499^{*} \\
(2.555)\end{array}$ \\
\hline Woman gets all & $\begin{array}{c}-5.195^{* *} \\
(-2.34)\end{array}$ & $\begin{array}{l}-0.334 \\
(-0.18)\end{array}$ & $\begin{array}{l}-4.893 \\
(-1.40)\end{array}$ & $\begin{array}{c}-5.933^{* * * *} \\
(1.803)\end{array}$ & $\begin{array}{c}0.023 \\
(1.589)\end{array}$ & $\begin{array}{l}-5.224^{*} \\
(2.998)\end{array}$ \\
\hline Sharing $\mathrm{x}$ wage & $\begin{array}{c}1.739^{* *} \\
(2.41)\end{array}$ & $\begin{array}{l}0.348 \\
(0.62)\end{array}$ & $\begin{array}{l}-0.053 \\
(-0.06)\end{array}$ & $\begin{array}{c}2.227 * * * \\
(0.687)\end{array}$ & $\begin{array}{l}-0.270 \\
(0.596)\end{array}$ & $\begin{array}{l}-0.938 \\
(0.939)\end{array}$ \\
\hline Separate $\mathrm{x}$ wage & $\begin{array}{c}2.408^{* * * *} \\
(3.12)\end{array}$ & $\begin{array}{l}0.981 \\
(1.38)\end{array}$ & $\begin{array}{l}0.669 \\
(0.57)\end{array}$ & $\begin{array}{c}2.681 \text { **** } \\
(0.813)\end{array}$ & $\begin{array}{c}1.117 \\
(0.678)\end{array}$ & $\begin{array}{c}0.491 \\
(1.105)\end{array}$ \\
\hline Woman gets all $\mathrm{x}$ wage & $\begin{array}{c}2.177^{* *} \\
(2.17)\end{array}$ & $\begin{array}{l}-0.314 \\
(-0.56)\end{array}$ & $\begin{array}{l}0.598 \\
(0.54)\end{array}$ & $\begin{array}{c}2.697 * * * \\
(0.841)\end{array}$ & $\begin{array}{l}-0.574 \\
(0.643)\end{array}$ & $\begin{array}{l}-0.088 \\
(1.082)\end{array}$ \\
\hline Sharing $\mathrm{x}$ partner's wage & $\begin{array}{l}-0.306 \\
(-0.45)\end{array}$ & $\begin{array}{l}-0.011 \\
(-0.01)\end{array}$ & $\begin{array}{l}1.538 \\
(1.13)\end{array}$ & $\begin{array}{l}-0.619 \\
(0.774)\end{array}$ & $\begin{array}{c}0.495 \\
(0.709)\end{array}$ & $\begin{array}{l}2.492^{* *} \\
(1.084)\end{array}$ \\
\hline Separate $\mathrm{x}$ partner's wage & $\begin{array}{l}-0.177 \\
(-0.24)\end{array}$ & $\begin{array}{l}-0.448 \\
(-0.58)\end{array}$ & $\begin{array}{l}2.044 \\
(1.49)\end{array}$ & $\begin{array}{l}-0.222 \\
(0.706)\end{array}$ & $\begin{array}{l}-0.681 \\
(0.748)\end{array}$ & $\begin{array}{l}2.151^{*} \\
(1.273)\end{array}$ \\
\hline Woman gets all x partner's wage & $\begin{array}{l}1.104 \\
(1.32)\end{array}$ & $\begin{array}{l}0.253 \\
(0.29)\end{array}$ & $\begin{array}{l}2.072 \\
(1.38)\end{array}$ & $\begin{array}{c}1.028 \\
(0.814)\end{array}$ & $\begin{array}{c}0.359 \\
(0.712)\end{array}$ & $\begin{array}{c}2.737^{* *} \\
(1.320)\end{array}$ \\
\hline Price in other round & & & & $\begin{array}{c}-1.993^{* * * *} \\
(0.539)\end{array}$ & $\begin{array}{l}-0.027 \\
(0.406)\end{array}$ & $\begin{array}{l}-0.351 \\
(0.681)\end{array}$ \\
\hline Partner's other price & & & & $\begin{array}{l}-0.543 \\
(0.551)\end{array}$ & $\begin{array}{l}-0.237 \\
(0.645)\end{array}$ & $\begin{array}{c}-2.563^{* * *} \\
(0.820)\end{array}$ \\
\hline Sharing, other round & & & & $\begin{array}{l}-1.799 \\
(1.508)\end{array}$ & $\begin{array}{l}-1.000 \\
(1.406)\end{array}$ & $\begin{array}{l}-2.924 \\
(2.173)\end{array}$ \\
\hline Separate, other round & & & & $\begin{array}{c}-3.658^{* *} \\
(1.553)\end{array}$ & $\begin{array}{l}-1.624 \\
(1.802)\end{array}$ & $\begin{array}{c}-6.038^{* *} \\
(2.610)\end{array}$ \\
\hline Woman gets all, other round & & & & $\begin{array}{c}-5.458^{* * *} \\
(1.762)\end{array}$ & $\begin{array}{c}0.553 \\
(1.527)\end{array}$ & $\begin{array}{l}-5.224^{*} \\
(2.766)\end{array}$ \\
\hline Sharing $\mathrm{x}$ wage, other round & & & & $\begin{array}{l}1.178^{*} \\
(0.695)\end{array}$ & $\begin{array}{l}-0.207 \\
(0.577)\end{array}$ & $\begin{array}{l}-1.070 \\
(1.014)\end{array}$ \\
\hline Separate $\mathrm{x}$ wage, other round & & & & $\begin{array}{c}2.405^{* * *} \\
(0.862)\end{array}$ & $\begin{array}{c}0.437 \\
(0.681)\end{array}$ & $\begin{array}{c}0.459 \\
(1.060)\end{array}$ \\
\hline Woman gets all $\mathrm{x}$ wage, other round & & & & $\begin{array}{c}2.353^{* * *} \\
(0.805)\end{array}$ & $\begin{array}{l}-0.995^{*} \\
(0.586)\end{array}$ & $\begin{array}{l}-0.293 \\
(1.045)\end{array}$ \\
\hline Sharing x partner's wage, other round & & & & $\begin{array}{l}-0.253 \\
(0.815)\end{array}$ & $\begin{array}{c}0.483 \\
(0.762)\end{array}$ & $\begin{array}{l}2.099^{*} \\
(1.067)\end{array}$ \\
\hline Separate x partner's wage, other round & & & & $\begin{array}{l}-0.149 \\
(0.650)\end{array}$ & $\begin{array}{c}0.151 \\
(0.901)\end{array}$ & $\begin{array}{l}2.950^{* *} \\
(1.277)\end{array}$ \\
\hline Woman gets all x partner's wage, other round & & & & $\begin{array}{c}0.897 \\
(0.763)\end{array}$ & $\begin{array}{c}0.386 \\
(0.756)\end{array}$ & $\begin{array}{c}2.918^{* *} \\
(1.280)\end{array}$ \\
\hline Mean peer output & & & & $\begin{array}{c}0.206^{* *} \\
(0.103)\end{array}$ & $\begin{array}{c}0.260^{* * *} \\
(0.095)\end{array}$ & $\begin{array}{c}0.541^{* * *} \\
(0.179)\end{array}$ \\
\hline Peer rule 1 & & & & $\begin{array}{c}0.118 \\
(0.222)\end{array}$ & $\begin{array}{c}0.445^{* *} \\
(0.212)\end{array}$ & \\
\hline Peer rule 2 & & & & $\begin{array}{c}-0.451^{* *} \\
(0.196)\end{array}$ & $\begin{array}{c}-0.467^{* *} \\
(0.197)\end{array}$ & \\
\hline Natural log of household consumption & & & & $\begin{array}{l}-0.118 \\
(0.162)\end{array}$ & $\begin{array}{c}0.370^{* *} \\
(0.147)\end{array}$ & $\begin{array}{c}0.267 \\
(0.321)\end{array}$ \\
\hline Acres owned & & & & $\begin{array}{l}0.055^{* *} \\
(0.022)\end{array}$ & $\begin{array}{c}0.029 \\
(0.025)\end{array}$ & $\begin{array}{l}0.084^{*} \\
(0.050)\end{array}$ \\
\hline Member of local majority ethnic group & & & & $\begin{array}{l}-0.220 \\
(0.350)\end{array}$ & $\begin{array}{c}-0.916^{* *} \\
(0.431)\end{array}$ & $\begin{array}{l}-1.090 \\
(0.842)\end{array}$ \\
\hline Household size & & & & $\begin{array}{c}0.050 \\
(0.037)\end{array}$ & $\begin{array}{l}-0.036 \\
(0.037)\end{array}$ & $\begin{array}{l}-0.001 \\
(0.077)\end{array}$ \\
\hline Highest grade of education completed by this person & & & & $\begin{array}{c}0.151 * * * \\
(0.050)\end{array}$ & $\begin{array}{c}0.141 * * * \\
(0.043)\end{array}$ & $\begin{array}{c}0.111 \\
(0.078)\end{array}$ \\
\hline Partner's education (highest grade) & & & & $\begin{array}{l}-0.012 \\
(0.041)\end{array}$ & $\begin{array}{c}0.052 \\
(0.043)\end{array}$ & $\begin{array}{l}0.229 * * \\
(0.089)\end{array}$ \\
\hline Year born & & & & $\begin{array}{c}0.070^{* * * *} \\
(0.025)\end{array}$ & $\begin{array}{c}0.085^{* * *} \\
(0.024)\end{array}$ & $\begin{array}{c}0.065 \\
(0.043)\end{array}$ \\
\hline Year partner born & & & & $\begin{array}{l}-0.011 \\
(0.021)\end{array}$ & $\begin{array}{l}-0.025 \\
(0.021)\end{array}$ & $\begin{array}{c}0.049 \\
(0.046)\end{array}$ \\
\hline Women responsible for food and money & & & & $\begin{array}{c}-0.924^{* *} \\
(0.393)\end{array}$ & $\begin{array}{c}0.018 \\
(0.989)\end{array}$ & $\begin{array}{l}-1.218 \\
(2.605)\end{array}$ \\
\hline Co-working Index & & & & $\begin{array}{c}0.137 \\
(0.318)\end{array}$ & $\begin{array}{c}-0.649^{* *} \\
(0.248)\end{array}$ & $\begin{array}{l}-0.584 \\
(0.584)\end{array}$ \\
\hline Women power over decisions & & & & $\begin{array}{l}0.974^{*} \\
(0.532)\end{array}$ & $\begin{array}{c}0.554 \\
(0.540)\end{array}$ & $\begin{array}{c}0.776 \\
(1.196)\end{array}$ \\
\hline Fraction of land where wife has veto rights & & & & $\begin{array}{c}-0.860^{* *} \\
(0.428)\end{array}$ & $\begin{array}{c}0.152 \\
(0.391)\end{array}$ & $\begin{array}{l}-0.638 \\
(1.048)\end{array}$ \\
\hline Fraction of plots where wife is main decision-maker & & & & $\begin{array}{l}-0.243 \\
(0.482)\end{array}$ & $\begin{array}{c}-0.925^{* *} \\
(0.413)\end{array}$ & $\begin{array}{l}-1.007 \\
(0.828)\end{array}$ \\
\hline Round 2 dummy & $\begin{array}{c}2.228^{* * *} \\
(12.86)\end{array}$ & $\begin{array}{c}2.075 * * * \\
(17.32)\end{array}$ & $\begin{array}{c}4.339^{* * *} \\
(18.26)\end{array}$ & $\begin{array}{c}1.913^{* * *} \\
(0.337)\end{array}$ & $\begin{array}{c}1.666^{* * *} \\
(0.268)\end{array}$ & $\begin{array}{c}3.269^{* * *} \\
(0.413)\end{array}$ \\
\hline Observations & 416 & 416 & 416 & 400 & 400 & 400 \\
\hline R-squared & 0.250 & 0.264 & 0.339 & 0.412 & 0.481 & 0.520 \\
\hline
\end{tabular}


is not significantly negative and in some cases it is positive. It is also the case that there is a significant (at the 10\% level) negative impact of a partner's wage rise on women's output. What is intriguing here is that effect of a wage rise in the other round has a similar impact on output in the current round. In fact, here the mean effect across all allocation rules is significantly negative, not just the case where 'men get all'.

Result 3. Raising female wages lowers female output and the effect is strongest when income goes to men.

Turning to the male equation, with or without controls there are no significant effects of own wages or partner's wages from either round (see Table 9), though the signs of the coefficients match the expectation given the results shown for relative output. It appears therefore that the negative link between relative wages and output reported in Table 6 is a combination of small effects from wages on the behaviour of both women and men. Based on the coefficients in Table 9, the net effect of a rise in male wages, for example, is a small drop in male output and a small drop in female output. The net effect is a drop in total output but the effect on relative output is ambiguous. In contrast, the effect of a rise in female wages is a fall in female output and a rise in male output and thus we have a fall in relative wages generating a rise in relative output. In short it is changes in female wages that appear to drive the result in Table $6 .{ }^{18}$

To sum up, the effects for men:

Result 4. Men typically do not respond to changes in the rules of the game, although there is some evidence that when income is paid separately rather than going to the man, male output falls.

What is the impact of the rules on overall household production? To examine this, we regress the sum of wife and husband's output on the control variables and the results are reported in the columns marked 'Total' in Table 8. To interpret the results, Table 10 shows the marginal effects for household output. It can be see that the net effect of a rise in male wages is to lower household output. A test that the coefficient on male and female wages are equal is not rejected at standard levels of statistical significance $(p=0.15)$. The effect of manipulating the other control variables is not significant with the exception of a switch from Male control to Sharing which lowers output at the $10 \%$ level of significance.

\footnotetext{
${ }^{18}$ The other intriguing aspect of Table 9 is the trend for women in the coefficients for own wages. It appears that as their entitlement to the income rise, the slope of the supply function trends to the positive.
} 
Table 9: Absolute Output Marginal effects.

\begin{tabular}{|c|c|c|c|c|c|c|c|c|}
\hline & \multicolumn{4}{|c|}{ Current round variables } & \multicolumn{4}{|c|}{ Other round variables } \\
\hline & \multicolumn{2}{|c|}{ Female with controls } & \multicolumn{2}{|c|}{ Male with controls } & \multicolumn{2}{|c|}{ Female with controls } & \multicolumn{2}{|c|}{ Male with controls } \\
\hline & $\mathrm{dy} / \mathrm{dx}$ & p-value & $\mathrm{dy} / \mathrm{dx}$ & p-value & $\mathrm{dy} / \mathrm{dx}$ & p-value & $\mathrm{dy} / \mathrm{dx}$ & p-value \\
\hline & \multicolumn{4}{|c|}{ Current own wage } & \multicolumn{4}{|c|}{ Other round own wage } \\
\hline Own wage (mean effect) & -0.403 & 0.144 & -0.373 & 0.176 & $-0.634^{* *}$ & 0.024 & -0.172 & 0.475 \\
\hline Man gets all & $-2.237 * * *$ & 0.000 & 0.432 & 0.248 & $-1.993^{* * *}$ & 0.000 & -0.027 & 0.948 \\
\hline Sharing & -0.011 & 0.982 & -0.702 & 0.116 & $-0.815^{*}$ & 0.099 & -0.234 & 0.612 \\
\hline Separate & 0.444 & 0.447 & 0.685 & 0.195 & 0.412 & 0.477 & 0.410 & 0.408 \\
\hline \multirow[t]{2}{*}{ Woman gets all } & 0.459 & 0.532 & -1.006 & $0.071^{*}$ & 0.360 & 0.583 & $-1.021^{* *}$ & 0.034 \\
\hline & \multicolumn{4}{|c|}{ Partner's wage } & \multicolumn{4}{|c|}{ Other round, partner's wage } \\
\hline Partner's wage (mean effect) & $-0.515^{* *}$ & 0.043 & 0.212 & 0.439 & $-0.500 *$ & 0.054 & 0.023 & 0.930 \\
\hline Man gets all & -0.443 & 0.375 & 0.138 & 0.816 & -0.543 & 0.327 & -0.237 & 0.714 \\
\hline Sharing & $-1.429^{* *}$ & 0.025 & 0.633 & $0.090^{*}$ & -0.796 & 0.109 & 0.245 & 0.505 \\
\hline Separate & -0.665 & 0.223 & -0.544 & 0.282 & -0.693 & 0.174 & -0.087 & 0.880 \\
\hline \multirow{2}{*}{ Woman gets all } & 0.585 & 0.391 & 0.497 & 0.408 & 0.353 & 0.571 & 0.148 & 0.772 \\
\hline & \multicolumn{4}{|c|}{ Entitlements } & \multicolumn{4}{|c|}{ Entitlements } \\
\hline Sharing & -0.023 & 0.946 & -0.393 & 0.190 & 0.014 & 0.966 & -0.473 & 0.116 \\
\hline Separate & 0.221 & 0.551 & $-0.686^{*}$ & 0.052 & 0.205 & 0.586 & $-0.776^{* *}$ & 0.015 \\
\hline Woman gets all & -0.101 & 0.832 & -0.158 & 0.693 & -0.015 & 0.975 & -0.157 & 0.637 \\
\hline
\end{tabular}

$\mathrm{dy} / \mathrm{dx}$ is the discrete first-difference from the base case (Man gets all). ${ }^{* * *} \mathrm{p}<0.01,{ }^{* *} \mathrm{p}<0.05{ }^{*} \mathrm{p}<0.1$

Table 10: Total Output Marginal effects.

\begin{tabular}{|c|c|c|c|c|}
\hline & \multicolumn{4}{|c|}{ Household output, with controls } \\
\hline & $\mathrm{dy} / \mathrm{dx}$ & p-value & \multicolumn{2}{|c|}{ Other tests } \\
\hline Man's wage & $-0.814^{* *}$ & 0.023 & \multicolumn{2}{|c|}{ Man's wage effect-women's wage effect $=0: p=0.15$} \\
\hline Women's wage & -0.059 & 0.974 & & \\
\hline Sharing & $-0.866^{*}$ & 0.072 & & \\
\hline Separate & -0.471 & 0.380 & & \\
\hline \multirow[t]{2}{*}{ Woman gets all } & -0.736 & 0.220 & & \\
\hline & \multicolumn{2}{|c|}{ Female wages } & Male wag & \\
\hline Male gets all & $-1.990^{*}$ & 0.053 & -0.720 & 0.224 \\
\hline Sharing & 0.657 & 0.261 & $-1.669^{* * *}$ & 0.005 \\
\hline Separate & 0.132 & 0.896 & -0.166 & 0.843 \\
\hline Women gets all & 0.631 & 0.578 & -0.626 & 0.503 \\
\hline
\end{tabular}


Result 5. Raising male wages lowers household output and the effect is strongest when income is shared. When Man get all the income, a rise in female wages lowers household income. On the other hand, when income is shared a rise in male wages lowers output.

In studies of fairness there is often evidence that responses to advantageous unfairness are different and weaker than responses to disadvantageous unfairness. This asymmetry is built in to the well-known model of Fehr and Schmidt (1999) and it is also a feature of Akerlof and Yellen (1990). To investigate this possibility we re-estimate, adding additional terms to the equations with controls in Table 8. Specifically we add interactions between current round price variables and the entitlement dummies and a dummy that is zero when the own price is larger than or equal to the partner's price and positive when the own price is smaller than the partner's price. Table 11 shows the resulting coefficients, omitting all the controls for brevity.

These results provide support for the main conclusion that men are not particularly sensitive to the treatment effect, whereas for women the most visible responses to treatment occur when men receive all the income. On the other hand, the evidence of asymmetries is much less clear. The coefficient for women on wage is strongly positive when all income is shared and the woman's wage rate is below that of the man's. Meanwhile there is some evidence of a negative coefficient for men, when the man controls all the income. Looking at the marginal effects in Table 12, rather than the coefficients, suggests that there is no strong evidence of an asymmetric reaction to wages except for the sharing case for women. In Table 12, none of the marginal effects for wages have overlapping confidence intervals for the corresponding marginal effect when the partner has higher wages, with the exception of the female output, sharing case. What stands out, again, is the difference in behaviour between the man gets all case and the other cases. $^{19}$

It is possible that there is heterogeneity in the response to wage and property rights changes. Obviously, with only have two rounds of data, we have limited ability to investigate this issue within individual households. We cannot, for example, estimate wage elasticities at the individual level and then relate them to household characteristics. In-

\footnotetext{
${ }^{19}$ Another source of asymmetries are caused by reference dependent preferences and this kind of explanation has been used in well-known papers to explain backward bending daily labour supply for taxi-drivers (Farber (2008); Camerer et al. (1997); Crawford and Meng (2011) in the USA, Dupas and Robinson (2013) for Kenya). Here, though the working time is fixed and it is not clear that the daily target for income fits the framing of our experiment. Moreover, at the heart of the reference dependent models used to explain the taxi-driver data, are shocks to wage rates caused by the weather and other demand shifters. Here wage rates are transparent and known to the subjects before they start the experiment. Moreover, we only find backward bending labour supply under certain property rights and not for example, when subjects receive only their own earnings. Still, as a robustness check we estimate a model which includes an interactive term for whether the current wage is higher or lower than the wage in the other round. We do not find any evidence for this kind of asymmetry in our data and so do not pursue it further.
} 
Table 11: Asymmetric Effects from Wages.

\begin{tabular}{lcc}
\hline & $(1)$ & $(2)$ \\
\hline VARIABLES & Fairness Women & Fairness Men \\
\hline Price per straw (own wage) & $-2.413^{* * *}$ & $-1.715^{* *}$ \\
& $(0.683)$ & $(0.765)$ \\
Partner's wage & -0.322 & 1.213 \\
& $(0.622)$ & $(0.900)$ \\
Sharing & $-3.338^{* *}$ & -1.584 \\
& $(1.487)$ & $(1.299)$ \\
Separate & $-4.096^{* *}$ & -1.566 \\
& $(1.627)$ & $(1.413)$ \\
Woman gets all & $-6.283^{* * *}$ & -0.667 \\
& $(1.879)$ & $(1.582)$ \\
Sharing x wage & $2.914^{* * *}$ & 1.433 \\
& $(0.885)$ & $(1.321)$ \\
Separate x wage & $2.887^{* * *}$ & 1.663 \\
& $(1.011)$ & $(1.101)$ \\
Woman gets all x wage & $3.080^{* * *}$ & 0.796 \\
Sharing x partner's wage & $(1.095)$ & $(0.906)$ \\
Separate x partner's wage & -1.284 & -1.002 \\
Woman gets all x partner's wage & $(0.842)$ & $(1.453)$ \\
Man gets all x wage x Partner's wage higher & -0.466 & -1.035 \\
Sharing x wage x Partner's wage higher & $(0.893)$ & $(1.224)$ \\
Separate x wage x Partner's wage higher & 0.748 & -0.817 \\
Woman gets all x wage x Partner's wage higher & $(0.980)$ & $(1.005)$ \\
Price in other round & -0.521 & $-1.698^{*}$ \\
Partner's other price & $(0.938)$ & $(0.882)$ \\
Observations & $2.808^{* * *}$ & 0.501 \\
R-squared & $(1.019)$ & $-1.216)$ \\
*Standard errors clustered at the village level in parentheses;** p $<0.01, ~$ & ** & $180.05, * \mathrm{p}<0.1$ \\
\hline
\end{tabular}


Table 12: Asymmetries in Marginal effects.

\begin{tabular}{|c|c|c|c|c|}
\hline & $\mathrm{dy} / \mathrm{dx}$ & p-value & $\mathrm{dy} / \mathrm{dx}$ & $\mathrm{p}$-value \\
\hline Female output & \multicolumn{2}{|c|}{ Female wages } & \multicolumn{2}{|c|}{ Female wages, partner has higher wage } \\
\hline Male gets all & $-2.143^{* * *}$ & 0.001 & $-2.933^{*}$ & 0.052 \\
\hline Sharing & 0.500 & 0.327 & $3.309 * *$ & 0.018 \\
\hline Separate & 0.474 & 0.483 & 0.777 & 0.598 \\
\hline Women gets all & 0.667 & 0.483 & 1.177 & 0.554 \\
\hline Male output & \multicolumn{2}{|c|}{ Male wages } & \multicolumn{2}{|c|}{ Male wages, partner has higher wage } \\
\hline Male gets all & $-1.715^{* *}$ & 0.027 & $-3.412^{* *}$ & 0.036 \\
\hline Sharing & -0.282 & 0.801 & 0.220 & 0.924 \\
\hline Separate & -0.052 & 0.951 & -1.052 & 0.579 \\
\hline Women gets all & -0.758 & 0.258 & -0.758 & 0.669 \\
\hline
\end{tabular}

stead, we re-estimate the models reported in Table 8, but allowing for the possibility of interactions between household characteristics and the coefficient on the wage variable. To do this we use eight variables ${ }^{20}$ that might reflect attitudes and beliefs within the household: the female power index; congruence (recall this variable measures agreement on questions about gender norms); beliefs about whether a partner would not share the experimental winnings; whether the husband or wife has more leisure $(0=$ husband, $1=$ neither and 2 = wife); female has the prime responsibility for food and money decisions; the fraction of plots where the wife has a veto on land transactions; the share of plots where the female makes decisions and finally who has most personal spending money (coded the same way as the leisure variable). With the exception of the leisure and spending, the value of these variables lies between 0 and 1 . The results ${ }^{21}$ are in Table 13 and seem to suggest that men's behaviour is more heterogeneous across these four variables, compared to women. For women, two of the interactive effects are statistically significant: the leisure variable, where women are more likely to respond to higher wages by lowering effort, if they believe that they have more leisure than their husbands; and the female responsibility variable where higher control rights for women is linked to a more positive effort response to wage rises. Men raise their responsiveness to wages when they report that their wives have more leisure or have more personal money. These contrasting

\footnotetext{
${ }^{20}$ We have no clear theory about which variables should be most appropriate, so for that reason we choose a relatively large selection. For men the highest absolute value of correlation within these variables is 0.32 for the female share and female responsibility variables. For women the strongest correlation is -0.42 between the female power index and congruence, which suggests that these different variables do capture different things about intra-household relations.

${ }^{21}$ That the sample sizes are lower in this table is due to the fact that we allowed a 'don't know' response to the share-a-windfall question.
} 
effects for the leisure variable may be due to leisure time and personal money reflecting the balance of power in the household. Meanwhile the coefficients on the "Partner would share winnings" variable suggests an element of reciprocity in men's behaviour, but not for women. This last point is notable, because one possible explanation of women's backward bending labour supply when men receive all the income is that they believe men will not share that income. However, the insignificant coefficient on the variable for women ${ }^{22}$ suggests that their behaviour is not driven by this fear.

Men also show a positive response to female power and a negative response to congruence. What is perhaps most notable is that the differences in the coefficients between genders are statistically significant at the $5 \%$ level for the first five variables - men and women seem to have opposite responses to these features of the household. The size of some of these effects is also large relative to the baseline coefficients on wage rates. For example, when the female responsibility variable equals 1, then women's response to wage rises is zero or positive across all the allocation rules. In contrast, when the variable is zero, women's response is highly negative when men get all the income and otherwise insignificantly different from zero.

Result 6. Measures of intra-household power and decision-making generally have different and opposite effects on the responsiveness of women and men to changes in wages.

\section{Conclusions.}

In a lab-in-the-field experiment in rural Uganda, we evaluate how changes in relative wage rates and entitlements affect behaviour in a series of tasks run with married couples. The wage rates and entitlements are randomly assigned to each individual and couple, respectively. Men and women work in separate production areas, making it impractical for the spouses to monitor each other's effort while they are performing their tasks. Nevertheless, when working, each spouse knows the rules that apply to their work and to their partners.

Our findings suggest that there is an inverse relationship between relative wage and relative output: partners paid relatively more work relatively less. This contradicts the most straightforward interpretation of the standard household model predictions of the effect of relative wage on relative output. We also find that the impact of relative wage on relative output can differ across allocation rules and is most pronounced when men receive all the income from the task. In other words, the magnitude of the impact will vary for different property rights categories. The behaviour is hard to reconcile with standard predictions. ${ }^{23}$ It is also inconsistent with some models of fairness such as that proposed

\footnotetext{
${ }^{22}$ And the fact reported earlier that most women expect their partners to share their earnings, at least to a degree.

${ }^{23}$ Historically - e.g. Berg (1961) - there has been some discussion of backward bending labour supply in sub-Saharan Africa. An interesting model by Dessing (2002) relates this to subsistence needs, but the
} 
Table 13: Interactive Effects and Wages.

\begin{tabular}{|c|c|c|}
\hline VARIABLES & Women & Men \\
\hline \multirow[t]{2}{*}{ Price per straw (own wage) } & $-1.677^{* *}$ & -1.033 \\
\hline & $(0.769)$ & $(0.682)$ \\
\hline \multirow[t]{2}{*}{ Partner's wage } & -0.592 & -0.021 \\
\hline & $(0.494)$ & $(0.485)$ \\
\hline \multirow[t]{2}{*}{ Sharing } & $-3.166^{* *}$ & -1.396 \\
\hline & $(1.524)$ & $(1.333)$ \\
\hline \multirow[t]{2}{*}{ Separate } & $-3.569 * *$ & -2.153 \\
\hline & $(1.731)$ & $(1.412)$ \\
\hline \multirow[t]{2}{*}{ Woman gets all } & $-6.438 * * *$ & -1.059 \\
\hline & $(1.990)$ & $(1.489)$ \\
\hline \multirow[t]{2}{*}{ Sharing $\mathrm{x}$ wage } & $2.138^{* * *}$ & -0.062 \\
\hline & $(0.744)$ & $(0.616)$ \\
\hline \multirow[t]{2}{*}{ Separate $\mathrm{x}$ wage } & $2.337^{* * *} *$ & $1.700 * *$ \\
\hline & $(0.828)$ & $(0.696)$ \\
\hline \multirow[t]{2}{*}{ Woman gets all $\mathrm{x}$ wage } & $2.750^{* * *}$ & -0.197 \\
\hline & $(0.938)$ & $(0.663)$ \\
\hline \multirow[t]{2}{*}{ Wage x Female Power } & -1.164 & $2.743^{*}$ \\
\hline & $(1.410)$ & $(1.631)$ \\
\hline \multirow[t]{2}{*}{ Wage x Congruence } & 0.012 & $-1.808^{* * *}$ \\
\hline & $(0.577)$ & $(0.577)$ \\
\hline \multirow[t]{2}{*}{ Wage $\mathrm{x}$ Partner shares winnings } & -0.086 & $0.321^{* *}$ \\
\hline & $(0.083)$ & $(0.133)$ \\
\hline \multirow{2}{*}{ Wage x Most leisure } & $-0.294^{* * *}$ & $0.159^{*}$ \\
\hline & $(0.101)$ & $(0.086)$ \\
\hline \multirow[t]{2}{*}{ Wage x Female Responsibility } & $2.220^{* *}$ & -1.810 \\
\hline & $(1.072)$ & $(1.351)$ \\
\hline \multirow[t]{2}{*}{ Wage x Female Land Veto } & 0.701 & -0.663 \\
\hline & $(0.803)$ & $(0.987)$ \\
\hline \multirow[t]{2}{*}{ Wage x Female Share } & -0.111 & -0.028 \\
\hline & $(1.076)$ & $(0.698)$ \\
\hline \multirow[t]{2}{*}{ Wage x Most Personal Money } & 0.052 & $0.220^{*}$ \\
\hline & $(0.141)$ & $(0.124)$ \\
\hline \multirow[t]{2}{*}{ Price in other round } & $-1.876^{* * *}$ & -0.248 \\
\hline & $(0.566)$ & $(0.360)$ \\
\hline \multirow[t]{2}{*}{ Partner's other price } & -0.693 & -0.295 \\
\hline & $(0.564)$ & $(0.505)$ \\
\hline Observations & 368 & 358 \\
\hline R-squared & 0.435 & 0.554 \\
\hline $\mathrm{F}$ & 25.45 & 37.66 \\
\hline Standard errors clustered at the & age leve & $\mathrm{p}<0.01,{ }^{* *} \mathrm{p}<0.05,{ }^{*} \mathrm{p}<0.1$ \\
\hline
\end{tabular}


by Akerlof and Yellen (1990). Nevertheless, the behaviour we observe may be motivated by feelings of fairness and intra-household justice, (e.g. Cappelen et al. (2010)) in which individuals have an ideal allocation rule such as a libertarian principle. In such a context, when income is paid out separately labour supply slopes upwards, but when income is pooled or goes to the other partner, higher wages may deepen feelings of unfairness and lead to lower effort. This interpretation is speculative: how concerns about fairness affect intra-household decisions requires further investigation.

Looking at the manipulation of property rights over the individual and relative output from the experiment, our results show that entitlements influence relative output in a manner that is not clearly supportive of any particular model. However, when we dig deeper and look at the response of individual output to changes in wages and allocation rules, we find that generally the women in our sample are more sensitive to rule changes than the men. In particular, it seems that the negative labour supply effect is driven by women's response when all the income goes to their husbands.

More than $80 \%$ of Uganda's population live in rural areas and most families depend mainly on agriculture (FAO, 2008). Since the customary law restricts the ability of women to claim rights to proceeds from the harvest; is there a possibly that this could deter the women's incentives to exert effort when working on the family farms? Conversely, would moves towards greater equality affect effort? Obviously, the long distance between the controlled circumstances of our experiment and major policy changes limits our ability to give definitive answers to such questions. Nevertheless, our experiment does suggest that changes in intra-household entitlements towards separation of earnings does not significantly lower productivity. In other words, the some adjustment of property rights for married people could be used as a tool to reduce gender inequality and this would have no negative effect on economic growth. These kinds of results are consistent with the macro-level evidence provided in Kabeer and Natali (2013). What shines through in our results though, is the interaction between wage equality and the rules of allocation. It is the combination that has the largest effect on productivity. Reforms that reduced wage inequality for example, but left intact property rules that favoured men might lead to negative productivity effects. Of course that is not a reason to avoid tackling inequalities, but it suggests that combining different equality reforms may be more effective than treating them as separate issues.

general arguments made in that literature relate to sustained changes in wages, rather than the temporary changes seen in our experiment. Moreover, if some kind of income target was driving behaviour in our experiment, then we would see backward bending labour supply across all allocation rules when in fact we only see it in a subset of rules and, reliably, for women. And note we have shown in Table 13 that there is no evidence that women's behaviour is driven by a fear that their earnings will be entirely kept by their husbands. 


\section{Appendix 1. English Language Version of the Instructions.}

[Bracketed items give guidance to enumerators. Note that all instruction was given in the local language, which varied from location to location.]

[STEP 1: All husbands AND wives together. General Introduction: If this is not the first session of the day, you don't have to say points 6 and 81

1. Welcome. Thank you for taking the time to come today. [Introduce EXPERIMENTERS and the assistants.] You can ask any of us questions during today's programme.

2. We have invited you here because we want to learn about how people work and make decisions.

3. There are several parts to this session, but here you are going to be asked to do a task TWO times for money. Each time everyone will work for 10 minutes

4. Whatever money you win today will be yours to keep.

5. All payments will be made at the end of all the experiments. What you need to do will be explained fully in a few minutes. But first we want to make a few things clear.

6. First, this is not our money. We belong to a university, and this money has been given to us for research.

7. Second, this is a study about how you work. Therefore you should not talk with others. This is very important. Please be sure to obey this rule because it is possible for one person to spoil the activity for everyone. I'm afraid that if we find you talking with others, we will have to send you home, and you will not be able to earn any money here today. Of course, if you have questions, you can ask one of us.

8. Third, the study has several parts. We will tell you about the other parts later on, after we have finished this part.

9. Finally, make sure that you listen carefully to us. You will be able to make a good amount of money here today, and it is important that the instructions are clear for you so that you can follow them. First we are going to explain about the work and then we will explain about the payment for the work.

[STEP 2. Explaining the work - one person speaks, another person does the showing]

I'm going to tell you about the work. Men will work in one place and women will work in a separate place, but you will all be doing the same job.

Here are some rubber bands [Hold up an example to everyone in the room] and some drinking straws [Hold up an example].You will be asked to collect rubber bands and straws from a table and take them back to where you are working. There you will need to tie 8 bands onto a straw. On each straw there must be 2 of each of these 4 colours. YELLOW [show] RED [show] BLUE [show] and GREEN [show]. When you have put the 8 bands on like this [show] and then put it on your table. There will be payment for each 
completed straw that is done correctly. [you can pass around a few bands so that people can

This straw [hold up correct example] is done correctly This straw [hold up straw ] does not have enough bands in it This straw [hold up straw] has the wrong mix of colours This straw [hold up straw] has all the straws on top of each other.

Now, XX [name of the other experimenter in the room] will show you how to do this. After she has shown you how to do it we will do a little practice.

[First, she takes some bands. Then she sorts out some coloured bands. She ties the bands on the straw. ]

So, in a moment we will do a practice. Everyone will go to the table once and bring back a few bands and make a straw correctly [if it's easier, you can pass out the straws and bands]. Let's check you understand so far: How many green bands must be on the straw [answer: 2]. How many red bands must be on the straw [ans:2]. How many blue bands must be on the straw [ans:2]. How many yellow bands [ans:2]

Okay, let's do a practice. [allow one go for each participant and check everyone to see that their straw is correct. If it's not, point it out to the person. Collect a few examples and show whether they are right or wrong. Don't time this bit: the aim is to teach the participants how to make a good straw] Everybody did a good practice. [answer questions]

\section{[STEP 3. Explaining the payment.]}

Let me tell about the payment. Remember that you going to do this task for 10 minutes twice so there are going to be two rules for payment. One for the first time and one for the second. All payments will be made at the end of all the experiments. In a moment I am going to ask each person in turn to pull a card from a cloth bag. This is the bag for the women [hold up a bag to be used for the women with a label 'woman' in English on one side and in the local language on the other side] What does this say? [wait for someone to shout out] And this is the bag for the men [hold up a bag to be used for the men, with the same kind of labelling. Ask again] [pull 2 cards from the men's bag, one 300 and one 600]. These cards show how much will be paid for each correctly done straw. You can see it's either 300 or 600 shillings that will be earned for every correctly done straw. After you have pulled a card from the bag, we will record that amount and then replace it for the next person. So every woman will have the same chance of getting 600 or 300 and every man will have the same chance of getting 600 or 300. [put the cards back in the bag] Let's do an example [Do a practice. take one card : one from the woman's bag and one from the men's bag. Show the numbers around the room and say what they mean. For example 300 is pulled from the mens' bag and 600 from the womans' bag. Then you would say, 'each straw completed properly by the man will pay 300 shillings and each straw completed properly by the woman will be paid 600 shillings' So if the man makes one straw the payment is 300 and he makes 2 straws the payment is 600 and so on. ]. 
So they are the amounts we will pay for every item that's correct.

Now, who gets the money? We have another bag. We call this the "Who gets the money bag" [hold up the bag and also point to the chart; ] Each couple will pull ONE card from this bag. Just one card per couple. There are four kinds of cards. [Hold up each in turn].

Can you see this card [you can also point to the chart]? If you pull this card [show ] all the money goes to the wife. That's all the money made by the husband and all the money made by the wife. If you pull this card [show ] all the money goes to the husband. That's all the money made by the husband and all the money made by the wife. If you pull this card [show ] all the money made by the husband will go the husband and all the money made by the wife, will be handed over to the wife. You will be paid separately. And If you pull this card [show ] all the money made by the husband and all the money made by the wife, will be added up and you will both get half of it. It will be shared equally.

Remember, after each couple has pulled a card we will put it back in the bag for the next draw.

Because you are doing the work twice, we will ask you to make all the draws from the bag twice.

First, each couple will pull one card from the women's bag and one card from the men's bag and one from the 'Who gets the money' bag. We will record your answers and replace the cards. Those cards will determine the payment rules for the first time you do the work.

Then you will do the same thing for the second time. This time you will be determining the rules of payment for the second time you do the work. The rules of payment might be the same, but they might not be.

For the 'who gets the money bag' the man will pull out the card for one of the tasks and the women will pull out the card for the other task.

We will record your answers and replace the cards and then circle your answer sheets as a reminder [point to chart and make everyone look at it then at their answer sheets] to show you the rules.

[point to sheet] At the top of the sheet will be rules for the first time you do the work. And at the bottom will be the rules for the second time. You will take your copy to remind you of the rules. Both times you will work for 10 minutes.

Let me tell you one more thing that's important. At the very end of the session today we will tell your husband or wife how much money you made and we will tell you how much money he made but we won't tell your spouse whether you worked hard or not. It's your choice how hard you work. Men and women work in different places so your spouse won't know how difficult the work is for you. And, there are lots more yellow bands than green or red and blue. They might get in your way and that's why your spouse won't know how hard the job was for you, just how many straws you made. 
Right, we are nearly ready to start.

[Bring forward each couple one at a time. Give each person an answer sheet.

1. Do rules of payment for task 1 first.

2. Each woman takes a card. Record its value and replace the card

3. Do the same for the man and the 'who gets the money card'. Either spouse can be responsible for taking the card from this bag. Record the answers and then do the same procedure again for the second task. Remind them why you are doing it twice.

4. Make sure the cards are replaced in the bags and both husband and wife have a fully completed reminder sheet. Then ask them to wait a little while the other couples are done.

5. When all couples are done]

Would wives now please go with [Thea] and husbands with [Theo]? [women and men go to separate rooms or separate places. Each person takes their answer sheets with them.]

[Instructions for Wives] (instructions for husbands mirror these and are omitted)

[Allocate each wife to a place in the room. Point to the rules for payment for the first round. ] We are nearly ready to start the first task. But first I want to check you understand.

[STEP 4: To be read- "Control Questions".]

Let me ask two questions to check whether you understood the instructions. 1 . If you have a card that says [300] and you make 2 items correctly, how many shillings will be paid? [correct people if necessary] 2. If you have a card that shows [point to card or hold an example] how will the paid? [all to your husband, all to you, shared equally or paid separately?] [correct participant if necessary.]

[Opportunity to ask questions of clarification.]

You have [10] minutes to work on your straws. We will start after 5. 5.4.3.2.1. Start!. [STEP 5]:

[Task is carried out SIMULTANEOUSLY by all wives. At the end, announce the end of 10 minutes. Count and check straws \& put the appropriate amount in the answer sheet on the 'how many straws' row. Also ask them how many straws they think their husbands made and fill this in.]

[STEP 6: To be read to all the women jointly].

Thank you for completing that task. Now we will do a second task . (The second task follows using the same template. Details are omitted.) 


\section{Appendix 2. Household Models.}

The unitary model: changes in absolute wages.

To see that the effect of changes in the own wages on effort is indeterminate, differentiate the first order conditions with respect to $w_{1}$ (the analysis for a rise in $w_{2}$ is symmetric) to produce,

$$
\left[\begin{array}{l}
e_{11} \\
e_{21}
\end{array}\right]=-H^{-1}\left[\begin{array}{c}
U^{\prime}+e_{1} w_{1} U^{\prime \prime} \\
w_{2} e_{1} U^{\prime \prime}
\end{array}\right]
$$

where $e_{i 1}$ refers to the derivative of the ith person's effort with respect to a change in wage 1 and $H$ is the Hessian for the maximization problem. That is,

$$
H=\left[\begin{array}{cc}
w_{1}^{2} U^{\prime \prime}-\lambda c_{1}^{\prime \prime} & w_{2} w_{1} U^{\prime \prime} \\
w_{2} w_{1} U^{\prime \prime} & w_{2}^{2} U^{\prime \prime}-(1-\lambda) c_{2}^{\prime \prime}
\end{array}\right]
$$

It follows that,

$$
\left[\begin{array}{l}
e_{11} \\
e_{21}
\end{array}\right]=\frac{1}{|H|}\left[\begin{array}{c}
-\left(w_{2}^{2} U^{\prime \prime}-(1-\lambda) a_{2}\right)\left(w_{1} e_{1} U^{\prime \prime}+U^{\prime}\right)+e_{1} w_{1} w_{2}^{2} U^{\prime \prime^{2}} \\
w_{2} U^{\prime \prime}\left(w_{1} U^{\prime}+e_{1} a_{1} \lambda\right)
\end{array}\right]
$$

or,

$$
\left[\begin{array}{l}
e_{11} \\
e_{21}
\end{array}\right]=\frac{1}{|H|}\left[\begin{array}{c}
(1-\lambda) U^{\prime} c_{2}^{\prime \prime}-U^{\prime \prime} w_{2}^{2} U^{\prime}+U^{\prime \prime}(1-\lambda) w_{1} e_{1} c_{2}^{\prime \prime} \\
w_{2} U^{\prime \prime}\left(w_{1} U^{\prime}+e_{1} c_{1}^{\prime \prime} \lambda\right)
\end{array}\right]
$$

where $|H|$ is the determinant of the Hessian. In this equation, the concavity of $\mathrm{U}$ means that $e_{21}$ is clearly negative. However, the sign of $e_{11}$ is ambiguous and depends on the relative size of the income and substitution effects. The income effect is proportional to:

$$
\left[\begin{array}{l}
e_{1 y} \\
e_{2 y}
\end{array}\right]=\frac{-U^{\prime \prime}}{|H|}\left[\begin{array}{c}
-(1-\lambda) w_{1} a_{2} \\
-\lambda w_{2} a_{1}
\end{array}\right]
$$

\section{References}

Agarwal, B., 1994. A field of one's own: Gender and land rights in South Asia. Cambridge University Press, Cambridge.

Agarwal, B., 1997. "Bargaining" and gender relations: Within and beyond the household. Feminist economics 3, 1-51. 
Akerlof, G.A., Yellen, J.L., 1990. The fair wage-effort hypothesis and unemployment. The Quarterly Journal of Economics , 255-283.

Ali, D.A., Collin, M., Deininger, K., Dercon, S., Sandefur, J., Zeitlin, A., 2016. Small price incentives increase women's access to land titles in Tanzania. Journal of Development Economics 123, 107-122.

Aoyagi, C., Munro, A., 2018. Work experience and preference for household production roles: An experiment. National Graduate Institute for Policy Studies .

Appleton, S., Emwanu, T., Kagugube, J., Muwonge, J., 1999. Changes in poverty in Uganda, 1992-1997. CASE WPS/99.22 .

Apusigah, A.A., 2009. The gendered politics of farm household production and the shaping of women's livelihoods in Northern Ghana. Feminist Africa 12, 51-67.

Asiimwe, J., 2014. Making women's land rights a reality in Uganda: Advocacy for coownership by spouses. Yale Human Rights and Development Journal 4, 8.

Becker, G., 1991. A treatise on the family, 1991. Enlarged Edition (Cambridge, Mass.: Harvard University Print) .

Becker, G.S., 1974. A theory of social interactions. The Journal of Political Economy 82, 1063-1093.

Berg, E.J., 1961. Backward-sloping labor supply functions in dual economies-the Africa case. The Quarterly Journal of Economics , 468-492.

Boserup, E., 1970. Women in economic development. London: Earthscan .

Breza, E., Kaur, S., Shamdasani, Y., 2017. The morale effects of pay inequality. The Quarterly Journal of Economics 133, 611-663.

Browning, M., Chiappori, P.A., 1998. Efficient intra-household allocations: A general characterization and empirical tests. Econometrica , 1241-1278.

Browning, M., Deaton, A., Irish, M., 1985. A profitable approach to labor supply and commodity demands over the life-cycle. Econometrica 53, 503-543.

Camerer, C., Babcock, L., Loewenstein, G., Thaler, R., 1997. Labor supply of New York City cabdrivers: One day at a time. The Quarterly Journal of Economics , 407-441.

Cappelen, A.W., Hole, A.D., Sørensen, E.Ø., Tungodden, B., 2007. The pluralism of fairness ideals: An experimental approach. The American Economic Review 97, 818827. 
Cappelen, A.W., Sørensen, E.Ø., Tungodden, B., 2010. Responsibility for what? fairness and individual responsibility. European Economic Review 54, 429 - 441. doi:https://doi.org/10.1016/j.euroecorev.2009.08.005.

Carruthers, B.G., Ariovich, L., 2004. The sociology of property rights. Annual Review of Sociology , 23-46.

Charness, G., Kuhn, P., 2007. Does pay inequality affect worker effort? experimental evidence. Journal of labor economics 25, 693-723.

Chen, Z., Woolley, F., 2001. A Cournot-Nash model of family decision making. The Economic Journal 111, 722-748.

Chiappori, P.A., 1992. Collective labor supply and welfare. Journal of Political Economy , 437-467.

Cochard, F., Couprie, H., Hopfensitz, A., 2018. What if women earned more than their spouses? an experimental investigation of work-division in couples. Experimental Economics 21, 50-71. doi:10.1007/s10683-017-9524-5.

Couprie, H., Cudeville, E., Sofer, C., et al., 2015. Efficiency versus Stereotypes: an Experiment in Domestic Production. Technical Report. Université Panthéon-Sorbonne (Paris 1), Centre d'Economie de la Sorbonne.

Crawford, V.P., Meng, J., 2011. New York City cab drivers' labor supply revisited: Reference-dependent preferences with rational expectations targets for hours and income. The American Economic Review 101, 1912-1932.

Dasgupta, U., Mani, S., 2015. Only mine or all ours: Do stronger entitlements affect altruistic choices in the household. World Development 67, 363-375.

Deere, C.D., Doss, C.R., 2006. The gender asset gap: What do we know and why does it matter? Feminist Economics 12, 1-50.

Dessing, M., 2002. Labor supply, the family and poverty: the s-shaped labor supply curve. Journal of Economic Behavior \& Organization 49, 433-458.

Doss, C., 2013. Intrahousehold bargaining and resource allocation in developing countries. The World Bank Research Observer 28, 52-78.

Doss, C., Meinzen-Dick, R., Bomuhangi, A., 2014. Who owns the land? perspectives from rural Ugandans and implications for large-scale land acquisitions. Feminist economics $20,76-100$. 
Doss, C., Truong, M., Nabanoga, G., Namaalwa, J., 2012. Women, marriage and asset inheritance in Uganda. Development Policy Review 30, 597-616.

Dupas, P., Robinson, J., 2013. Daily needs, income targets and labor supply: evidence from kenya. National Bureau of Economic Research .

Engelmann, D., 2012. How not to extend models of inequality aversion. Journal of Economic Behavior \& Organization 81, 599-605.

FAO, 2008. Land access in rural Africa: Strategies to fight gender inequality. FAODimitra workshop .

Farber, H.S., 2008. Reference-dependent preferences and labor supply: The case of New York City taxi drivers. The American Economic Review 98, 1069-1082.

Farmer, A., Tiefenthaler, J., 1995. Fairness concepts and the intrahousehold allocation of resources. Journal of Development Economics 47, 179-189.

Feder, G., Nishio, A., 1998. The benefits of land registration and titling: economic and social perspectives. Land use policy 15, 25-43.

Fehr, E., Goette, L., 2007. Do workers work more if wages are high? evidence from a randomized field experiment. The American Economic Review 97, 298-317.

Fehr, E., Schmidt, K.M., 1999. A theory of fairness, competition, and cooperation. Quarterly journal of Economics , 817-868.

Gächter, S., Thöni, C., 2010. Social comparison and performance: Experimental evidence on the fair wage effort hypothesis. Journal of Economic Behavior \& Organization 76, $531-543$.

Goette, L., Huffman, D., Fehr, E., 2004. Loss aversion and labor supply. Journal of the European Economic Association 2, 216-228.

Goldberg, J., 2011. Kwacha gonna do? experimental evidence about labor supply in rural Malawi. University of Michigan .

Greiner, B., Ockenfels, A., Werner, P., 2011. Wage transparency and performance: A real-effort experiment. Economics Letters 111, 236-238.

Hoel, J.B., 2015. Heterogeneous households: A within-subject test of asymmetric information between spouses in Kenya. Journal of economic behavior \& organization 118, 123-135. 
Holden, S., Bezu, S., 2013. Joint land certification and intra-household decision-making: Towards empowerment of wives? Centre for Land Tenure Studies, Norwegian University of Life Sciences .

Iversen, V., Jackson, C., Kebede, B., Verschoor, A., Munro, A., 2010. Do spouses realise cooperative gains? Experimental evidence from rural Uganda. World Development 39, $569-578$.

Jones, C., 1983. The mobilization of women's labor for cash crop production: A game theoretic approach. American Journal of Agricultural Economics 65, 1049-1054.

Kabeer, N., Natali, L., 2013. Gender equality and economic growth: Is there a win-win? IDS Working Papers 2013, 1-58.

Kagundu, P., Pavlova, O., 2007. Gender wage differentials in Uganda: Evidence from the Uganda national household survey. Andrew Young School of Policy Studies Research Paper Series .

Kasirye, I., 2011. Addressing gender gaps in the ugandan labour market. Policy Briefs 150532, Economic Policy Research Centre (EPRC). .

Katz, E., 1997. The intra-household economics of voice and exit. Feminist economics 3, 25-46.

Kebede, B., Munro, A., Tarazona-Gomez, M., Verschoor, A., 2014. Intra-household efficiency: An experimental study from Ethiopia. Journal of African Economies 23, $105-150$.

Lastarria-Cornhiel, S., 2003. Uganda country brief: property rights and land markets. University of Wisconsin-Madison: Land Tenure Center .

Liu-Kiel, H., Cadsby, C.B., Schenk-Mathes, H.Y., Song, F., Yang, X., 2013. A crosscultural real-effort experiment on wage-inequality information and performance. The BE Journal of Economic Analysis \& Policy 13, 1095-1120.

Munro, A., Kebede, B., Tarazona-Gomez, M., Verschoor, A., 2010. The lion's share. An experimental analysis of polygamy in Northern Nigeria. GRIPS Discussion Papers .

Munro, A., Kebede, B., Tarazona-Gomez, M., Verschoor, A., 2014. Autonomy and efficiency. an experiment on household decisions in two regions of India. Journal of the Japanese and International Economies 33, 114-133.

Munro, A., Verschoor, A., Dubey, A., 2013. Does working with spouses make teams more productive? A field experiment in India using NREGA. Economics Letters 118, $506-508$. 
Mwesigye, F., Matsumoto, T., 2016. The effect of population pressure and internal migration on land conflicts: Implications for agricultural productivity in Uganda. World Development 79, 25-39.

Newman, C., Tarp, F., Van Den Broeck, K., 2015. Property rights and productivity: The case of joint land titling in Vietnam. Land Economics 91, 91-105.

Ovonji-Odida, I., Muhereza, F., Eturu, L., Wily, L., 2000. Land, gender and poverty eradication, is there a case for spousal co-ownership of primary household property. Land Act Implementation Project, Kampala, Uganda .

Schober, T., Winter-Ebmer, R., 2011. Gender wage inequality and economic growth: is there really a puzzle?a comment. World Development 39, 1476-1484.

Schröder, M., Schmitt, N., Heynemann, B., Brünn, C., 2013. Income taxation and labor supply: An experiment on couple's work effort. Beiträge zur Jahrestagung des Vereins für Socialpolitik 2013: Wettbewerbspolitik und Regulierung in einer globalen Wirtschaftsordnung - Session: Tax Evasion and Labor Supply, No. C06-V3 .

Sen, A.K., 1987. Gender and cooperative conflicts. WIDER.

Tanaka, Y., Munro, A., 2014. Regional variation in risk and time preferences: Evidence from a large-scale field experiment in rural Uganda. Journal of African Economies 23, $151-187$.

Warr, P.G., 1983. The private provision of a public good is independent of the distribution of income. Economics letters 13, 207-211.

Wiig, H., Bråten, R.H., Orge-Fuetens, D., 2012. Land ownership and women's empowerment - combining survey and experiments in Peruvian rural households. Background Paper for World Development Report, 2012 .

World Bank, 2005. World development report 2006: Equity and development. Oxford University Press, Incorporated.

World Bank, 2012. World development report 2012: Gender equality and Development. Oxford University Press, Incorporated.

Yamano, T., Sserunkuuma, D., Otsuka, K., Omiat, G., Ainembabazi, J.H., Shimamura, Y., 2004. The 2003 REPEAT survey in Uganda: results. FASID Development Database , 09-01. 